EESTI NSV TEADUSTE AKADEEMIA TOIMETISED 1952. I-k. nr. 4 ИЗВЕСТИЯ АКАДЕМИИ НАУК ЭСТОНСКОИ ССР 1952. Том I, № 4

\title{
ОПЫТ ИНТЕНСИВНОГО ВЫРАЩИВАНИЯ МОЛОДНЯКА КРУПНОГО РОГАТОГО СКОТА ЭСТОНСКОЙ КРАСНОЙ ПОРОДЫ
}

\author{
П. Я. АРАНДИ, \\ кандидат сельскохозяйственных наук
}

В постановлении пленума секции животноводства Всесоюзной ордена Ленина Академии сельскохозяйственных наук имени В. И. Ленина (1-5 февраля 1951 г.) к существенным недостаткам в изучении и разработке различных проблем питания сельскохозяйственных. животных отнесена также и «слабая разработка различных типов кормления и корморых рационов соответственно особенностям колхозов и совхозов различных географических зон СССР и уровню продуктивности сельскохозяйственных животных».

В деле выращивания молодняка кормление является мощным фактором, направляющим развитие молодых животных. Учитывая важность проблемы питания животных, Институт животноводства и ветеринарии в настоящее время главное внимание уделяет разработке эффективных типов кормления с целью определения наиболее рационального соотношения отдельных видов кормов в рационах, которое наиболее соответствовало бы экономическим интересам колхозов и совхозов и физиологическим потребностям животных. Кроме того, разрабатываемой системой кормления имеется в виду направлять развитие пищеварительного тракта молодняка так, чтобы он во взрослом состоянии мог усваивать возможно большее количество местных грубых и сочных кормов и перерабатывать их в большие количества молока.

В опытах на молодняке эстонской красной породы, проведенных на Тяхтвереской экспериментальной базе Института животноводства и ветеринарии АН ЭССР, применялось несколько типов различного уровня кормления. В настоящей работе изложены результаты опыта с двумя группами телят до годовалого возраста. Опыт имел целью изучение метбдов интенсивного кормления с тем, чтобы максимально использовать энергию роста молодняка для повышения скороспелости, живого веса и продуктивности коров. Также имелось в виду выяснить мясные качества эстонской красной породы, которая до сих пор разводилась главным образом в молочном направлении. Комплектование подопытных групп происходило с февраля по апрель 1950 года. Характеристика подопытных животных приведена в табл. 1.

Молодняк, происходящий от коров третьего отела и старше, был включен в опыт со дня рождения. Животные содержались в индивидуальных клетках до 6-7-месячного возраста, после чего они прикреплялись на привязь к стойлу. 
Характеристика подопытного молодняка эстонской
красной породы

\begin{tabular}{|c|c|c|c|c|c|}
\hline $\begin{array}{l}\text { Подопытные } \\
\text { группы }\end{array}$ & $\begin{array}{c}\text { Количество } \\
\text { голов }\end{array}$ & $\begin{array}{c}\text { Средний живой } \\
\text { вес при рож- } \\
\text { дении } \\
\text { кг }\end{array}$ & Поколепие & $\begin{array}{c}\text { Средняя про- } \\
\text { дуктивность } \\
\text { матерей за } 300 \\
\text { дней лактации } \\
\text { кг }\end{array}$ & $\begin{array}{c}\text { Средний жи- } \\
\text { вой вес мате- } \\
\text { рей } \\
\text { кг }\end{array}$ \\
\hline I rрyпna & & & $\begin{array}{l}\text { Четвертое - } \\
\text { чистопород- }\end{array}$ & & \\
\hline телки & 7 & 33,8 & ное & 3317 & 500 \\
\hline бБічки & 7 & 36,3 & $n$ & 3547 & 493 \\
\hline II rpynna & & & & & \\
\hline телки & 6 & 33,6 & , & 3211 & 490 \\
\hline & 7 & & - & 2923 & 480 \\
\hline
\end{tabular}

Телят выпускали на прогулку на свежем воздухе с 2-3-недельного возраста. В зимний период длительность ежедневных прогулок была в зависимости от погоды $1-3$ часа. В летний сезон подопытный молодняк днем находился в загоне, расположенном рядом с телятником, а на ночь его впускали в помещение. Такая система содержания обеспечила животных необходимым моционом на свежем воздухе.

При составлении плана роста (табл. 2) исходили из того положения, чтобы живой вес молодняка обеих групп превышал требования бонитировки класса элита-рекорд у животных первой группы до $15 \%$, а у второй до $30 \%$.

Т а блиц а 2

План роста подопытного молодняка

\begin{tabular}{|c|c|c|c|c|c|c|c|c|c|}
\hline \multirow[b]{2}{*}{$\begin{array}{c}\text { Подопытные } \\
\text { группы }\end{array}$} & \multirow{2}{*}{ 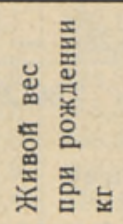 } & \multicolumn{2}{|c|}{ До 3 мес. } & \multicolumn{2}{|c|}{ 4-6 мес. } & \multicolumn{2}{|c|}{ 7-9 мес. } & \multicolumn{2}{|c|}{$10-12$ мес } \\
\hline & & 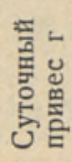 & 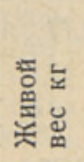 & 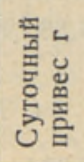 & 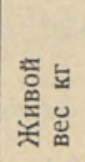 & 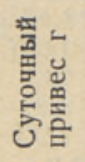 & 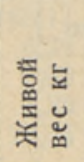 & 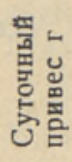 & 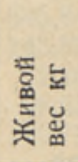 \\
\hline I группа & & & & & & & & & \\
\hline телки & $30-32$ & 750 & 95 & 850 & 180 & 650 & 240 & 600 & 300 \\
\hline бычки & $32-36$ & 850 & 110 & 950 & 200 & 750 & 270 & 675 & 330 \\
\hline II группа & & & & & & & & & \\
\hline Т слки & $30-32$ & 850 & 110 & 950 & 200 & 750 & 270 & 675 & 330 \\
\hline бычки & $32-36$ & 950 & 120 & 1050 & 215 & 875 & 290 & 725 & 350 \\
\hline
\end{tabular}

\section{Кормление молодняка и расход кормов}

Кормление телят первой группы было запланировано довольно интенсивным, а второй группы даже обильным. Так, было предусмотрено выпоить молодняку первой группы до 400 кг цельного молока и до 1200 кг обрата, а молодняку второй группы, соответственно, до 600 кг и 1500 кг. В первом полугодии обе группы получали равные количества концентрированных кормов. Во втором же полугодии животным первой группы предполагалось скармливать по 1,5-2,0 кг, а второй группе по $2,5-3,0$ кг концентратов в день. Концентрированный корм состоял глав- 
ным образом из овсяной муки и жмыхов (соевые, подсолнечные). Грубые, сочные и зеленые корма имелось в виду давать обеим группам без ограничения.

Кормление было индивидуальным, все заданные корма и несъеденные остатки взвешивались. В летний период зеленый корм косили два раза в день и давали животным в кормушки в свежем виде. Загон для прогулки телят был освобожден от всякой растительности, чтобы избежать возможности бесконтрольного поедания корма животными.

Все заданные корма подвергались полному зоотехническому анализу, на основе которого вычислялось съеденное животными количество питательных веществ.

Данные потребления кормов приведены в табл. 3 .

$\mathrm{T}$ а блиц а 3

Потребление кормов в среднем на одну голову в течение первого года( в кг)

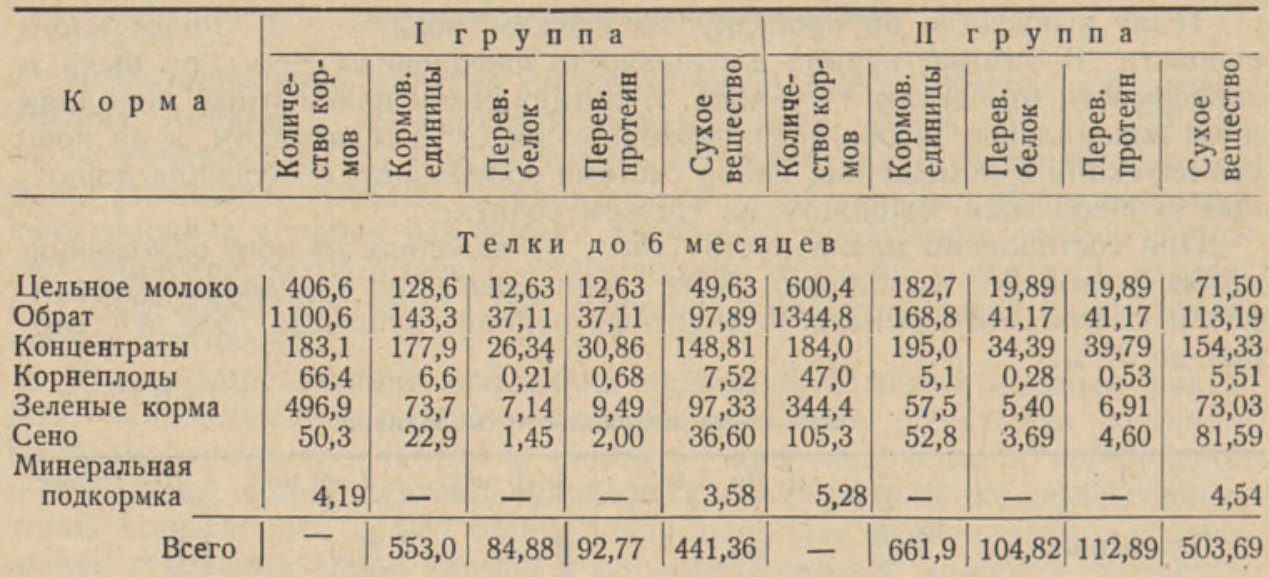

Телки от 7 до 12 месяцев

\begin{tabular}{l|r|r|r|r|r|r|r|r|r|r} 
Обрат & 73,3 & 8,4 & 2,23 & 2,23 & 5,76 & 152,2 & 16,3 & 4,80 & 4,80 & 11,22 \\
Концентраты & 320,7 & 359,8 & 71,06 & 80,98 & 286,11 & 532,1 & 581,3 & 125,25 & 140,27 & 481,53 \\
Корнеплоды & 964,6 & 101,9 & 4,54 & 10,20 & 116,24 & 1125,3 & 111,0 & 5,37 & 11,66 & 124,40 \\
Картофель & 455,4 & 146,5 & 3,63 & 6,51 & 106,14 & - & - & - & - & - \\
$\begin{array}{c}\text { Зеленые корма } \\
\text { Сено }\end{array}$ & 190,8 & 37,0 & 3,42 & 4,33 & 43,81 & - & - & - & - & - \\
$\begin{array}{c}\text { Минеральная } \\
\text { подкормка }\end{array}$ & 724,6 & 345,0 & 23,48 & 31,28 & 567,72 & 777,2 & 349,6 & 23,17 & 32,07 & 603,58 \\
\hline & 17,22 & - & - & - & 14,87 & 15,68 & - & - & - & 13,50 \\
\hline
\end{tabular}

Телки от рождения до 12 месяцев

\begin{tabular}{l|r|r|r|r|r|r|r|r|r|r} 
Цельное молоко & 406,6 & 128,6 & 12,63 & 12,63 & 49,63 & 600,4 & 182,7 & 19,89 & 19,89 & 71,50 \\
Обрат & 1173,9 & 151,7 & 39,34 & 39,34 & 103,65 & 1497,0 & 185,1 & 45,97 & 45,97 & 124,41 \\
Концентраты & 503,8 & 537,7 & 97,40 & 111,84 & 434,92 & 716,1 & 776,3 & 159,64 & 180,06 & 635,86 \\
Корнеплоды & 1031,0 & 108,5 & 4,75 & 10,88 & 123,76 & 1172,3 & 116,1 & 5,65 & 12,19 & 129,91 \\
Картофель & 455,4 & 146,5 & 3,63 & 6,51 & 106,14 & - & - & - & - & - \\
Зеленые корма & 687,7 & 110,7 & 10,56 & 13,82 & 141,14 & 344,4 & 57,5 & 5,40 & 6,91 & 73,03 \\
Сено & 774,9 & 367,9 & 24,93 & 33,28 & 604,32 & 882,5 & 402,4 & 26,86 & 36,67 & 685,17 \\
$\begin{array}{c}\text { Минеральная } \\
\text { подкормка }\end{array}$ & 21,41 & - & - & - & 18,45 & 20,96 & - & - & - & 18,04 \\
\hline
\end{tabular}


Т а бли ц а 3 (продолжение)

\begin{tabular}{|c|c|c|c|c|c|c|c|c|c|c|}
\hline \multirow[b]{2}{*}{$\mathrm{K} \circ \mathrm{p} \mathrm{M} \mathrm{a}$} & \multicolumn{5}{|c|}{ I r p y n n a } & \multicolumn{5}{|c|}{ II $\mathrm{r} p \mathrm{y} n \mathrm{n} \mathrm{a}$} \\
\hline & 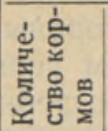 & 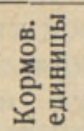 & 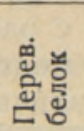 & 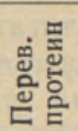 & 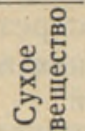 & 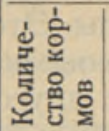 & 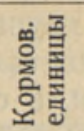 & 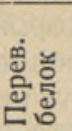 & 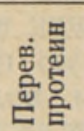 & 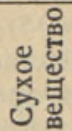 \\
\hline
\end{tabular}

Бычки до 6 месяцев

\begin{tabular}{l|r|r|r|r|r|r|r|r|r|r} 
Цельное молоко & 404,3 & 130,1 & 12,93 & 12,93 & 50,06 & 599,9 & 183,7 & 19,79 & 19,79 & 70,06 \\
Обрат & 1117,0 & 140,5 & 34,30 & 34,30 & 96,01 & 1378,8 & 175,9 & 43,51 & 43,51 & 118,37 \\
Концентраты & 210,4 & 228,8 & 40,86 & 47,21 & 180,47 & 196,6 & 208,5 & 36,28 & 41,83 & 165,59 \\
Корнеплоды & 133,0 & 15,6 & 0,84 & 1,60 & 16,56 & 50,9 & 5,8 & 0,29 & 0,59 & 6,22 \\
Картофель & 28,1 & 9,1 & 0,22 & 0,39 & 6,86 & - & - & - & - & - \\
Зеленые корма & 348,2 & 57,7 & 5,47 & 7,21 & 73,85 & 447,1 & 76,5 & 7,25 & 9,07 & 96,85 \\
$\begin{array}{l}\text { Сено } \\
\text { Минеральная } \\
\text { подкормка }\end{array}$ & 167,7 & 84,3 & 5,71 & 7,37 & 131,88 & 113,5 & 56,6 & 3,96 & 4,93 & 88,02 \\
\multicolumn{1}{|c|}{} \\
Всего
\end{tabular}

Бычки от 7 до 12 месяцев

\begin{tabular}{l|r|r|r|r|r|r|r|r|r|r} 
Oбрат & 90,2 & 10,5 & 2,83 & 2,83 & 7,19 & 119,2 & 12,8 & 3,71 & 3,71 & 8,78 \\
Концентраты & 359,5 & 395,7 & 82,75 & 92,79 & 326,04 & 528,7 & 585,9 & 128,89 & 143,25 & 480,25 \\
Корнеплоды & 1487,8 & 139,9 & 6,95 & 16,28 & 159,82 & 1267,1 & 123,3 & 5,95 & 12,89 & 139,65 \\
Картофель & 773,9 & 247,7 & 6,65 & 10,76 & 181,53 & 10,0 & 3,2 & 0,09 & 0,14 & 2,40 \\
$\begin{array}{l}\text { Зеленые корма } \\
\text { Сено }\end{array}$ & 24,7 & 5,6 & 0,50 & 0,60 & 6,12 & - & - & - & - & - \\
$\begin{array}{c}\text { Минеральная } \\
\text { подкормка }\end{array}$ & 725,7 & 326,1 & 21,85 & 30,92 & 563,48 & 814,0 & 375,5 & 25,58 & 35,00 & 631,76 \\
\multicolumn{1}{|c|}{16,90} & - & - & - & 14,63 & 17,40 & - & - & - & 14,99 \\
\hline
\end{tabular}

Бычки от рождения до 12 месяцев

\begin{tabular}{l|r|r|r|r|r|r|r|r|r|r} 
Цельное молоко & 403,1 & 130,1 & 12,93 & 12,93 & 50,06 & 599,9 & 183,7 & 19,79 & 19,79 & 70,06 \\
Обрат & 1207,2 & 151,0 & 37,13 & 37,13 & 103,20 & 1498,0 & 188,7 & 47,22 & 47,22 & 127,15 \\
Концентраты & 569,9 & 624,5 & 123,61 & 140,00 & 506,51 & 725,3 & 794,4 & 165,17 & 185,08 & 645,84 \\
Корнеплоды & 1620,8 & 155,5 & 7,79 & 17,88 & 176,38 & 1318,0 & 129,1 & 6,24 & 13,48 & 145,87 \\
Картофель & 802,0 & 256,8 & 6,87 & 11,15 & 188,39 & 10,0 & 3,2 & 0,09 & 0,14 & 2,40 \\
Зеленые корма & 372,9 & 63,3 & 5,97 & 7,81 & 79,97 & 447,1 & 76,5 & 7,25 & 9,07 & 96,85 \\
Сено & 893,4 & 410,4 & 27,56 & 38,29 & 695,36 & 927,5 & 432,1 & 29,54 & 39,93 & 719,78 \\
Минеральная & & & - & - & 19,65 & 22,52 & - & - & - & 19,39 \\
\hline подкормка & 22,73 & - & - & - & 19,05 & - &
\end{tabular}
Bcero $|-| 1791,6|221,86| 265,19|1819,52|-|1807,7| 275,30|314,71|_{1827,34}$

Несмотря на то, что телки второй группы вследствие значительного количества выпоенного им молока претерпевали большие трудности при переходе на растительные корма, все же в течение первых 6 месяцев они съедали грубых и сочных кормов на $11,18 \%$ больше, чем телки первой группы.

Этот результат показывает, что более умеренное потребление молочных кормов в настоящем опыте не вызвало большей поедаемости телками грубых и зеленых кормов, что отметили в своем опыте также И. А. Лебедев и А. П. Семенов $\left({ }^{3}\right)$. У бычков наблюдалось иное положение. Так, бычки первой группы съедали грубых, сочных и зеленых кормов на голову примерно на $10,6 \%$ больше по сравнению с бычками второй группы.

Во втором полугодии, когда молодняку второй группы давалось больше концентрированных кормов, у животных первой группы заметно проявилась способность съедать большие количества заданных им гру- 
бых, сочных и зеленых кормов. Так, телки первой группы съели в среднем на голову на 169,8 кг корм. ед.* или $36,9 \%$, а бычки на 217,8 кг корм. ед. или $43,4 \%$ больше грубых, сочных и зеленых кормов, чем молодняк второй группы. Этот результат, с одной стороны, указывает на бо́льшую поедаемость основных кормов молодняком первой группы во втором полугодии, а с другой - на различную потребность в наборе кормов со стороны телок и бычков, что ясно выразилось уже до 6-месячного возраста.

Это обстоятельство необходимо учитывать на практике при выращивании бычков для племенных целей и для забоя.

Итоги общего расхода кормов на питание подопытного молодняка от рождения до годовалого возраста даны в табл. 4.

\section{Соотношение скормленных кормов}

Та блиц а 4

\begin{tabular}{|c|c|c|c|c|}
\hline \multirow{2}{*}{$\begin{array}{l}\text { Подопытные } \\
\text { группы }\end{array}$} & \multicolumn{2}{|c|}{$\begin{array}{c}\text { Молоко и концентраты } \\
\text { кормов. ед. }\end{array}$} & \multicolumn{2}{|c|}{$\begin{array}{l}\text { Грубые, сочные и зеле- } \\
\text { ные корма - кормов. ед. }\end{array}$} \\
\hline & кг & $\%$ & кг & $\%$ \\
\hline $\begin{array}{l}\text { I группа } \\
\text { телки }\end{array}$ & 818,0 & 52,72 & 733,6 & 47,28 \\
\hline бычки & 906,2 & 50,53 & 886,3 & 49,47 \\
\hline $\begin{array}{l}\text { II г руппа } \\
\text { телки } \\
\text { бычки }\end{array}$ & $\begin{array}{l}1144,2 \\
1166,7\end{array}$ & $\begin{array}{l}66,52 \\
64,54\end{array}$ & $\begin{array}{l}576,0 \\
641,0\end{array}$ & $\begin{array}{l}33,48 \\
35,46\end{array}$ \\
\hline
\end{tabular}

Так как подопытные животные съедали максимальное количество кормов, до физиологического предела, то некоторый интерес представляют данные о расходе кормовых единиц и сухого вещества по отдельным месяцам жизни (табл. 5).

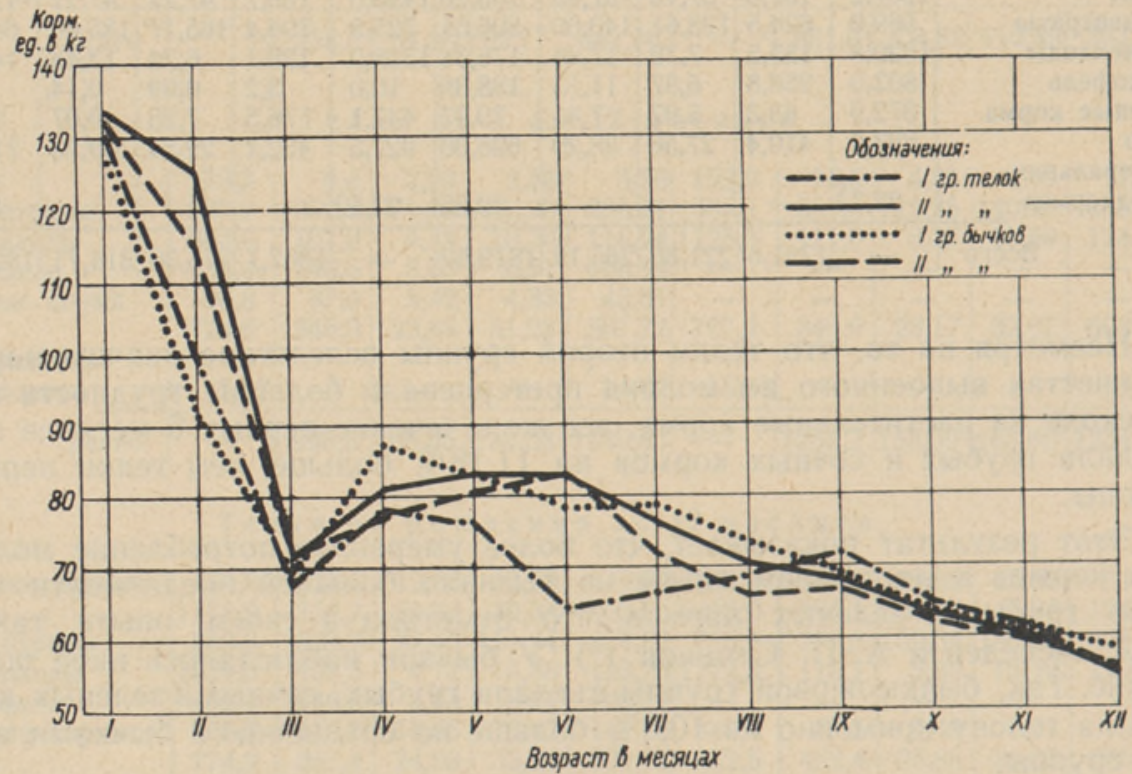

Рис. 1. Помесячное потребление кормов в кормовых единицах в кг на 100 кг живого веса

* В настоящей работе применяется эвсяная кормовая единища. 
Среднее помесячное потребление кормов подопытным молодняком до годовалого возраста

(В скобках показаны колебания)

\begin{tabular}{|c|c|c|c|c|c|c|}
\hline $\begin{array}{c}\text { Подопыт- } \\
\text { ные груп- } \\
\text { пы }\end{array}$ & $\begin{array}{c}\text { Кормов. } \\
\text { един. }\end{array}$ & $\begin{array}{c}\text { Сухое } \\
\text { вещество }\end{array}$ & $\begin{array}{c}\text { Кормов. } \\
\text { един. }\end{array}$ & $\begin{array}{c}\text { Сухое } \\
\text { вещество }\end{array}$ & $\begin{array}{c}\text { Кормов. } \\
\text { един. }\end{array}$ & $\begin{array}{c}\text { Сухое } \\
\text { вещество }\end{array}$ \\
\hline I группа & \multicolumn{2}{|c|}{ 1-й месяц } & \multicolumn{2}{|c|}{ 2-й месяц } & \multicolumn{2}{|c|}{ 3-й месяц } \\
\hline $\begin{array}{l}\text { телки } \\
\text { бычки }\end{array}$ & $\begin{array}{c}71,3 \\
(61,1-78,7) \\
74,1 \\
(68,4-78,3)\end{array}$ & $\begin{array}{c}27,8 \\
(25,7-30,3) \\
28,6 \\
(26,8-30,0)\end{array}$ & $\begin{array}{c}76,9 \\
(66,9-86,0) \\
72,3 \\
(66,2-78,9)\end{array}$ & $\begin{array}{c}38,9 \\
(32,5-41,4) \\
35,9 \\
(31,8-39,0)\end{array}$ & $\begin{array}{c}69,7 \\
(64,4-78,0) \\
76,0 \\
(67,1-84,3)\end{array}$ & $\mid \begin{array}{c}56,4 \\
(51,5-61,9) \\
64,4 \\
(56,5-71,9)\end{array}$ \\
\hline $\begin{array}{l}\text { II группа } \\
\text { гелки }\end{array}$ & 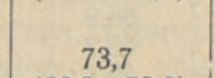 & 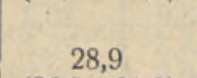 & $x^{2}+2=0$ & 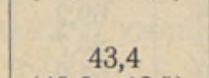 & 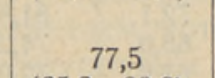 & 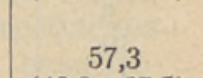 \\
\hline бычки & $\begin{array}{c}(66,3-79,8) \\
77,0 \\
(72,6-86,3)\end{array}$ & $\begin{array}{c}(26,0-31,3) \\
30,1 \\
(28,4-34,6)\end{array}$ & $\begin{array}{c}(100,6-108,1) \\
106,0 \\
(95,7-114,8)\end{array}$ & $\begin{array}{c}(40,6-46,0) \\
44,3 \\
(32,2-50,7)\end{array}$ & $\begin{array}{c}(65,2-90,9) \\
87,4 \\
(76,6-102,7)\end{array}$ & $\begin{array}{c}(43,0-67,5) \\
71,4 \\
(53,5-98,0)\end{array}$ \\
\hline I группа & \multicolumn{2}{|c|}{ 4-й месяц } & \multicolumn{2}{|c|}{ 5-й месяц } & \multicolumn{2}{|c|}{ 6-й месяц } \\
\hline $\begin{array}{l}\text { телки } \\
\text { бычки }\end{array}$ & $\mid \begin{array}{c}99,8 \\
(85,2-114,9) \\
122,7 \\
(103,4-134,5)\end{array}$ & $\begin{array}{c}88,02 \\
(73,4-109,3) \\
111,3 \\
(86,2-129,8)\end{array}$ & $\begin{array}{c}118,0 \\
(105,7-131,1) \\
139,6 \\
(118,1-166,7)\end{array}$ & $\begin{array}{c}110,4 \\
(99,0-120,8) \\
131,9 \\
(102,7-169,6)\end{array}$ & $\mid \begin{array}{c}117,4 \\
(104,1-147,3) \\
154,3 \\
(130,6-188,1)\end{array}$ & $\mid \begin{array}{c}120,0 \\
(109,4-142,9) \\
158,9 \\
(117,6-189,6)\end{array}$ \\
\hline II rрynna & & & & & & \\
\hline $\begin{array}{l}\text { телки } \\
\text { бычки }\end{array}$ & $\begin{array}{c}117,5 \\
(96,0-121,3) \\
115,9 \\
(90,7-130,3)\end{array}$ & $\begin{array}{c}96,6 \\
(85,3-108,4) \\
100,8 \\
(80,9-112,7)\end{array}$ & $\begin{array}{c}137,5 \\
(126,8-152,5) \\
141,9 \\
(130,7-158,6)\end{array}$ & $\begin{array}{c}125,3 \\
(117,3-146,5) \\
133,4 \\
(114,1-156,9)\end{array}$ & $\begin{array}{c}158,4 \\
(146,8-181,5) \\
168,4 \\
(151,5-185,4)\end{array}$ & $\begin{array}{c}153,3 \\
(134,0-186,5) \\
159,4 \\
(133,3-189,5)\end{array}$ \\
\hline
\end{tabular}

I rpynna

телки

бычки

Il группа

телки

бычки

I группа

телки

бычки

II rрyпna

телки

бычки 7-й месяц

$133,5 \quad 143,9$

$(108,6-144,1)(131,4-161,1)$

$175,6 \quad 185,4$

$(148,2-187,9)(153,8-198,6)$

166,4

$(152,7-183,3)$

167,2

$(152,4-181,5)(170,5-195,2)$

10-й месяц

175,9 | 201,2

$(160,8-192,1)(175,7-213,7)-(168,92,6$

| 8-й месяц

$155,0 \quad 173,0$

$(141,7-168,4)(175,1-181,2)$

182,1

201,9

$(173,8-197,3)(191,8-218,0)$

)

(

\begin{tabular}{c|c}
179,0 & 202,8 \\
$(152,8-190,2)$ & $(184,8-190,2)$ \\
188,4 & 216,7
\end{tabular}

$(209,6-222,2)$

\begin{tabular}{c|ccc}
170,6 & 192,4 & 180,6 & 210,6 \\
$(164,3-178,3)$ & $(179,5-214,0)$ & $(170,7-193,6)$ & $(193,0-222,7)$
\end{tabular}

\begin{tabular}{c|ccc}
170,6 & 192,4 & 180,6 & 210,6 \\
$(164,3-178,3)$ & $(179,5-214,0)$ & $(170,7-193,6)$ & $(193,0-222,7)$
\end{tabular}

171,7

197,6

182,4

211,4

11-й месяц

\section{2-й месяц}

\begin{tabular}{c|c}
172,6 & 205,0 \\
$(144,1-195,3)$ & $(154,7-237,0)$ \\
196,8 & 221,8 \\
$(166,7-214,4)$ & $(206,0-238,2)$
\end{tabular}

215,1

$\begin{array}{ccc}(164,7-214,3) & (175,2-241,7) & (165,8-251,5)\end{array}$

$(201,5-227,1)$

$(194,1-277,2)(166,7-214,4)$

$(206,0-238,2)$

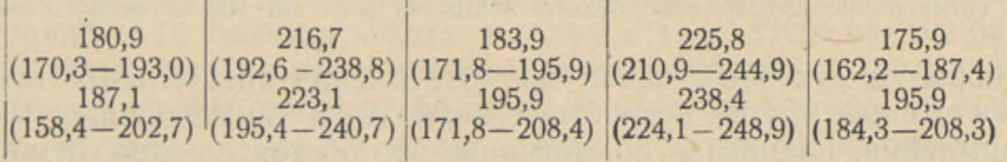

211,9

$(202,4-218,8)$

227,9

$(215,9-246,2)$

Данные, приведенные в табл. 5, показывают, что потребление питательных веществ из месяца в месяц, несколько колеблясь, постоянно увеличивается с повышением веса животных. Большой интерес представляют эти же данные и данные о потреблении сухого вешества рациона в пересчете на единицу живого веса (табл. 6, рис. 1 и 2 ). 
Расход кормов на 100 кг живого веса

Т а блиц а 6

\begin{tabular}{|c|c|c|c|c|c|c|c|c|}
\hline \multirow{4}{*}{$\begin{array}{l}\text { Воз- } \\
\text { раст в } \\
\text { меся- } \\
\text { цах }\end{array}$} & \multicolumn{4}{|c|}{ I rрyпnа } & \multicolumn{4}{|c|}{ II группа } \\
\hline & \multicolumn{2}{|c|}{ Телки } & \multicolumn{2}{|c|}{ Бычки } & \multicolumn{2}{|c|}{ Телки } & \multicolumn{2}{|c|}{ Бычки } \\
\hline & \multicolumn{8}{|c|}{ Израсходовано на 100 кг живого веса кг } \\
\hline & $\begin{array}{l}\text { Кормов. } \\
\text { единиц }\end{array}$ & $\begin{array}{c}\text { Сухого } \\
\text { вещества }\end{array}$ & $\begin{array}{l}\text { Кормов. } \\
\text { единиц }\end{array}$ & $\begin{array}{c}\text { Сухого } \\
\text { вещества }\end{array}$ & $\begin{array}{l}\text { Кормов. } \\
\text { единиц }\end{array}$ & $\begin{array}{c}\text { Сухого } \\
\text { вещества }\end{array}$ & $\begin{array}{l}\text { Кормов. } \\
\text { единиц }\end{array}$ & $\begin{array}{l}\text { Сухого } \\
\text { вещества }\end{array}$ \\
\hline $\begin{array}{r}1 \\
2 \\
3 \\
4 \\
5 \\
6 \\
7 \\
8 \\
9 \\
10 \\
11 \\
12\end{array}$ & $\begin{array}{r}130,4 \\
99,6 \\
67,8 \\
77,9 \\
75,8 \\
64,3 \\
66,4 \\
68,8 \\
72,1 \\
65,0 \\
61,9 \\
55,0\end{array}$ & $\begin{array}{l}50,9 \\
50,3 \\
54,8 \\
88,6 \\
71,0 \\
65,6 \\
75,5 \\
76,8 \\
81,6 \\
74,2 \\
72,9 \\
65,3\end{array}$ & $\begin{array}{r}127,8 \\
90,6 \\
69,4 \\
87,1 \\
82,7 \\
78,6 \\
78,6 \\
73,5 \\
69,2 \\
63,7 \\
61,9 \\
58,5\end{array}$ & $\begin{array}{l}49,3 \\
43,9 \\
58,7 \\
79,6 \\
78,9 \\
79,9 \\
88,0 \\
82,0 \\
79,9 \\
71,7 \\
70,1 \\
65,7\end{array}$ & $\begin{array}{r}134,1 \\
125,2 \\
71,4 \\
81,7 \\
83,2 \\
82,7 \\
76,3 \\
70,2 \\
68,9 \\
68,3 \\
60,5 \\
54,9\end{array}$ & $\begin{array}{l}52,5 \\
52,2 \\
52,6 \\
69,9 \\
75,9 \\
80,2 \\
81,1 \\
79,2 \\
80,3 \\
75,7 \\
68,8 \\
66,1\end{array}$ & $\begin{array}{r}132,6 \\
114,8 \\
71,9 \\
77,5 \\
80,6 \\
83,4 \\
72,1 \\
66,0 \\
66,9 \\
62,2 \\
59,7 \\
55,7\end{array}$ & $\begin{array}{l}51,5 \\
48,4 \\
58,6 \\
67,4 \\
74,9 \\
80,0 \\
78,1 \\
75,9 \\
76,4 \\
74,1 \\
72,7 \\
64,6\end{array}$ \\
\hline
\end{tabular}

Для того чтобы на основании этих опытных данных установить некоторые закономерности, необходимо прежде всего иметь в виду влияние качества кормового рациона и набора кормов (молоко, сочный или

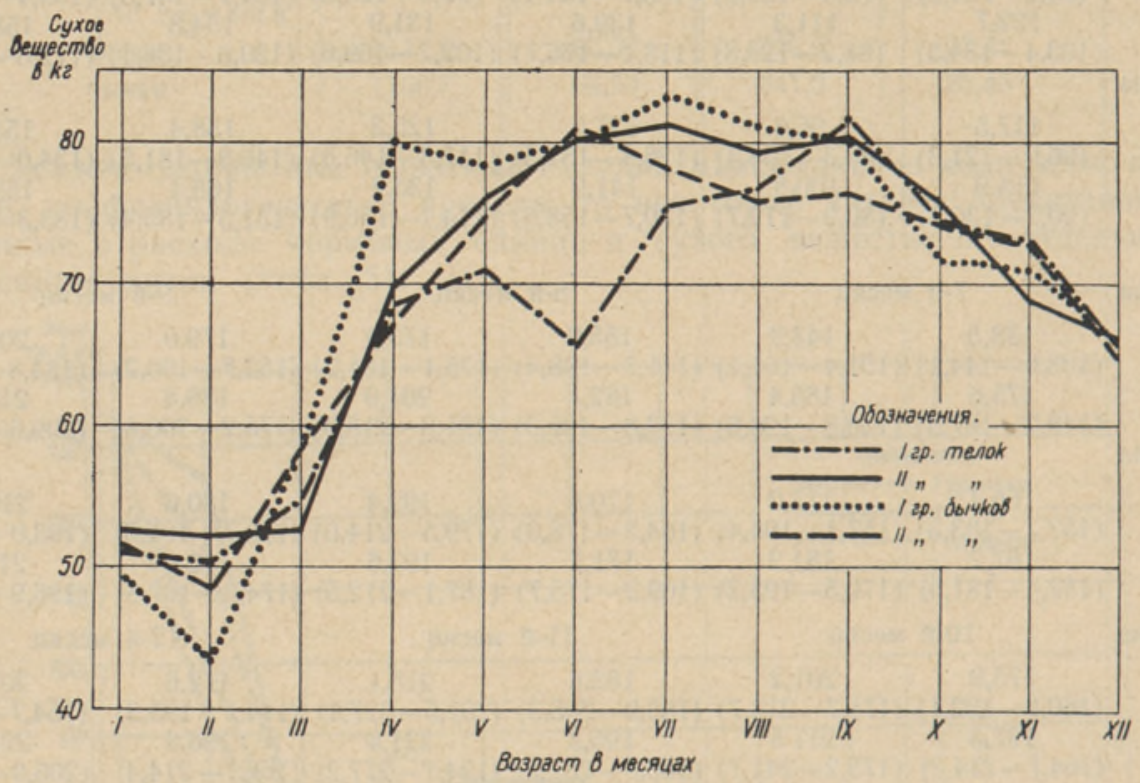

Рис. 2. Помесячное потребление сухого вещества в кг на 100 кг живого веса

зеленый корм) в суточных дачах на потребление питательных веществ животными в те или другие возрастные периоды, а также влияние уровня и типа кормления. Принимая во внимание это обстоятельство, отметим в качестве общей закономерности постоянное снижение потребления питательных веществ на единицу живого веса животного с первого месяца жизни до годовалого возраста. Крутое падение поедаемости до 3-месячного возраста явно обусловлено трудностями при переходе от молока на растительные корма. Эти трудности преодолеваются к 4-месячному возрасту. После 6-месячного возраста (за исключением телок I группы) 
происходит постоянное, хотя и медленное снижение потребления питательных веществ рационов молодняком до достижения годовалого возраста.

Если общая закономерность потребления питательных веществ на единицу живого веса дает некоторые исходные ориентировочные положения для составления схем и обоснования норм кормления молодняка по отдельным породам и зонам (для выращивания определенного типа животных), то кривые потребления сухого вещества представляют более сложное явление.

Само собою разумеется, что низкая поедаемость сухого вещества корма на единицу живого веса в первые месяцы жизни обусловлена анатомическими особенностями (недоразвитие преджелудков), а также физиологической функцией пишеварительного тракта и связана с характером кормления. При переходе на растительный корм потребление сухого вещества рациона резко повышается (рис. 2), но после 6-9-месячного возраста наблюдается постепенное снижение потребления сухого вещества. Причина такого явления связана с уменьшением потребления питательных веществ на единицу веса в связи с постепенным ослаблением энергии роста молодняка.

Более высокий уровень поедания сухого вещества корма телятами в возрасте от 4 до 9 месяцев объясняется особой физиологической потребностью в отношении объема кормового рациона в данном периоде роста молодняка. Полученные данные могут служить в качестве основы при составлении кормовых рационов, направляющих развитие пищеварительного тракта на переваривание и усвоение больших количеств грубых и сочных кормов. Исходя из того общебиологического принципа, что во время естественного интенсивного роста органы и ткани более податливы стимулирующему влиянию внешних факторов, мы имеем возможность в период 5-9 месяцев жизни наиболее эффективно направлять развитие пищеварительного тракта молодняка и выращивать из него коров, которые будут в состоянии перерабатывать большие дачи грубых и сочных кормов в высокие удои молока.

\section{Живой вес и прирост подопытного молодняка}

В таблицах 7 и 8 приведены данные по живому весу и приросту подопытного молодняка.

Между I и II группой молодняка в возрасте 1-12 месяцев не наблюдается большой разницы в живом весе.

По среднесуточным привесам у всех подопытных групп (за исключением бычков второй группы) характерным является то, что самый интенсивный рост происходит в 3-6-месячном возрасте (рис. 3).

Причины резких колебаний среднесуточных привесов во втором полугодии различны. Первое значительное снижение привесов (не наблюдавшееся у бычков первой группы) можно отчасти объяснить переходом от летнего кормления на зимнее. Иногда низкий привес обусловлен такими факторами, как болезни, охота у телок и т. д. Нередко вообще быв'ает трудно объяснить причину слабого роста, особенно в тех случаях, когда животные здоровы, съедают большие количества кормов, но все же дают низкие привесы. Такого рода задержки в росте являются каким-то «отдыхом», после которого в следующем месяце происходит мощный подъем в росте. Причина такого явления, повидимому, заключается в самом характере роста и развития и обусловлена глубокими биологическими факторами, подлежащими дальнейшему исследованию. Рис. 3 наглядно характеризует процессы роста и развития, которые не идут плавно, по восходящим и нисходяшцим линиям, а происходят довольно 


\begin{tabular}{|c|c|c|c|c|c|c|c|c|c|}
\hline \multirow{2}{*}{$\begin{array}{c}\text { Подопыт- } \\
\text { ные } \\
\text { группы }\end{array}$} & \multicolumn{9}{|c|}{ Живон вескг } \\
\hline & $\begin{array}{l}\text { При } \\
\text { рож- } \\
\text { дении }\end{array}$ & $\begin{array}{c}\text { Сред- } \\
\text { ний }\end{array}$ & Колебания & $\begin{array}{l}\text { Cpea- } \\
\text { ний }\end{array}$ & Колебания & $\begin{array}{l}\text { Сред- } \\
\text { ний }\end{array}$ & Колебания & $\begin{array}{c}\text { Сред- } \\
\text { ний }\end{array}$ & Колебания \\
\hline I группа & & 1 & м е с яц & $2 \mathrm{M}$ & 1 еся я а & & м есяц а & 4 & м ес я ц а \\
\hline $\begin{array}{l}\text { телки } \\
\text { бычки }\end{array}$ & $\begin{array}{l}33,9 \\
36,3\end{array}$ & $\begin{array}{l}54,7 \\
58,4\end{array}$ & $\begin{array}{l}46,5-58,1 \\
50,9-64,4\end{array}$ & $\begin{array}{l}77,6 \\
81,8\end{array}$ & $\begin{array}{l}68,0-80,6 \\
76,1-91,1\end{array}$ & $\begin{array}{l}103,0 \\
110,0\end{array}$ & $\begin{array}{l}92,5-107,7 \\
97,6-124,8\end{array}$ & $\left|\begin{array}{l}128,1 \\
141,1\end{array}\right|$ & $\mid \begin{array}{l}109,0-136,0 \\
129,6-161,1\end{array}$ \\
\hline & & & & & & & & & \\
\hline $\begin{array}{l}\text { телки } \\
\text { бычки }\end{array}$ & $\begin{array}{l}33,7 \\
38,1\end{array}$ & $\begin{array}{l}55,0 \\
62,0\end{array}$ & $\begin{array}{l}50,3-59,7 \\
53,9-66,9\end{array}$ & $\begin{array}{l}83,3 \\
91,6\end{array}$ & $\begin{array}{l}77,0-90,8 \\
85,0-97,0\end{array}$ & $\begin{array}{l}108,7 \\
121,4\end{array}$ & $\left|\begin{array}{l}101,3-116,2 \\
113,9-127,7\end{array}\right|$ & $\left|\begin{array}{l}136,9 \\
149,1\end{array}\right|$ & $\mid \begin{array}{l}123,1-150,2 \\
135,9-160,8\end{array}$ \\
\hline 1 группа & & $5 \mathrm{~m}$ & и еся це в & $6 \mathrm{M}$ & е сяцев & $7 \mathrm{~m} \mathrm{e}$ & ся цев & $8 \mathrm{~m}$ & еся иев \\
\hline $\begin{array}{l}\text { телки } \\
\text { бычки }\end{array}$ & & $\begin{array}{l}155,8 \\
169,9\end{array}$ & $\mid \begin{array}{l}136,2-165,9 \\
154,8-189,1\end{array}$ & $\left|\begin{array}{l}183,2 \\
200,0\end{array}\right|$ & $\mid \begin{array}{l}168,2-197,1 \\
184,0-223,7\end{array}$ & $\begin{array}{l}201,9 \\
223,3\end{array}$ & $\begin{array}{l}179,3-223,1 \\
202,6-263,7\end{array}$ & $\left|\begin{array}{l}226,1 \\
247,8\end{array}\right|$ & $\mid \begin{array}{l}204,4-243,1 \\
231,9-278,1\end{array}$ \\
\hline Il группа & & & & & & & & & \\
\hline $\begin{array}{l}\text { телки } \\
\text { бычки }\end{array}$ & & $\begin{array}{l}166,4 \\
178,2\end{array}$ & $\mid \begin{array}{l}147,7-183,7 \\
166,3-191,0\end{array}$ & $\left|\begin{array}{l}192,5 \\
205,4\end{array}\right|$ & $\begin{array}{l}173,7-210,7 \\
187,1-216,2\end{array}$ & $\mid \begin{array}{l}218,9 \\
232,7\end{array}$ & $\begin{array}{l}202,0-233,3 \\
219,3-243,0\end{array}$ & $\left|\begin{array}{l}243,5 \\
260,6\end{array}\right|$ & $\begin{array}{l}226,4-262,1 \\
247,9-273,9\end{array}$ \\
\hline I груп :a & & & и еся це в & $10 \mathrm{M}$ & меся я е в & $11 \mathrm{~N}$ & меся це в & $12 \mathrm{~m}$ & меся иев \\
\hline $\begin{array}{l}\text { телки } \\
\text { бычки }\end{array}$ & & $\begin{array}{l}249,2 \\
272,2\end{array}$ & $\begin{array}{l}229,7-263,5 \\
251,5-298,6\end{array}$ & $\begin{array}{l}270,8 \\
294,7\end{array}$ & $\begin{array}{l}249,9-289,6 \\
269,5-325,1\end{array}$ & $\begin{array}{l}295,2 \\
318,2\end{array}$ & $\begin{array}{l}261,9-318,9 \\
287,3-349,0\end{array}$ & $\mid \begin{array}{l}313,4 \\
338,9\end{array}$ & $\mid \begin{array}{l}276,1-348,5 \\
300,1-368,0\end{array}$ \\
\hline $\begin{array}{l}\text { II группа } \\
\text { телки } \\
\text { бычки }\end{array}$ & & $\begin{array}{l}262,7 \\
277,1\end{array}$ & $\begin{array}{l}250,2-282,8 \\
264,0-287,0\end{array}$ & $\left|\begin{array}{l}285,8 \\
301,0\end{array}\right|$ & $\begin{array}{l}270,4-300,2 \\
295,2-308,0\end{array}$ & $\begin{array}{l}304,4 \\
327,9\end{array}$ & $\begin{array}{l}280,0-317,0 \\
315,7-335,7\end{array}$ & $\left|\begin{array}{l}320,8 \\
352,3\end{array}\right|$ & $\mid \begin{array}{l}298,6-327,9 \\
337,3-359,0\end{array}$ \\
\hline
\end{tabular}

Суточные привесы подопытного молодняка

Т а бл иц а 8

\begin{tabular}{|c|c|c|c|c|c|c|c|c|}
\hline \multirow{2}{*}{$\begin{array}{c}\text { Подопыт- } \\
\text { ные } \\
\text { группы }\end{array}$} & \multicolumn{8}{|c|}{ Суточный привес г } \\
\hline & $\begin{array}{c}\text { Сред- } \\
\text { ний }\end{array}$ & Колебания & $\begin{array}{l}\text { Сред- } \\
\text { ний }\end{array}$ & Колебания & \begin{tabular}{|c|} 
Сред- \\
ний
\end{tabular} & Колебания & $\begin{array}{c}\text { Сред- } \\
\text { ний }\end{array}$ & Колебания \\
\hline & \multicolumn{2}{|c|}{1 м еся ц } & \multicolumn{2}{|c|}{2 м есяца } & \multicolumn{2}{|c|}{3 м ес я ца } & \multicolumn{2}{|c|}{4 м ес я ца } \\
\hline $\begin{array}{l}\text { телки } \\
\text { бычки }\end{array}$ & $\begin{array}{l}692 \\
725\end{array}$ & & $\begin{array}{l}756 \\
777\end{array}$ & & $\begin{array}{l}833 \\
919\end{array}$ & $\begin{array}{l}707-903 \\
694-1120\end{array}$ & $\left|\begin{array}{r}812 \\
1016\end{array}\right|$ & \\
\hline $\begin{array}{l}\text { II группа } \\
\text { телки }\end{array}$ & $\begin{array}{l}695 \\
776\end{array}$ & $\begin{array}{l}595-756 \\
604-901\end{array}$ & $\begin{array}{l}936 \\
977\end{array}$ & & $\begin{array}{l}829 \\
969\end{array}$ & $\begin{array}{l}694-959 \\
852-1122\end{array}$ & $\begin{array}{l}929 \\
912\end{array}$ & $\begin{array}{l}704-1132 \\
487-1178\end{array}$ \\
\hline 1 rpynna & \multicolumn{2}{|c|}{5 месяцев } & \multicolumn{2}{|c|}{6 месяцев } & \multicolumn{2}{|c|}{7 месяцев } & \multicolumn{2}{|c|}{8 месяцев } \\
\hline $\begin{array}{l}\text { Т. лки } \\
\text { бычки }\end{array}$ & $\begin{array}{l}924 \\
937\end{array}$ & & & & $\begin{array}{l}610 \\
599\end{array}$ & & $\begin{array}{l}799 \\
571\end{array}$ & \\
\hline $\begin{array}{l}\text { II груп } \\
\text { телкн } \\
\text { бычки }\end{array}$ & $\begin{array}{l}883 \\
944\end{array}$ & $\begin{array}{l}819-1080 \\
739-1076\end{array}$ & $\begin{array}{l}852 \\
886\end{array}$ & $\begin{array}{l}788-911 \\
693-1148\end{array}$ & $\begin{array}{l}809 \\
831\end{array}$ & $\begin{array}{l}754-991 \\
700-1058\end{array}$ & $\begin{array}{l}803 \\
907\end{array}$ & \\
\hline I группа & \multicolumn{2}{|c|}{9 месяцев } & \multicolumn{2}{|c|}{10 месядев } & \multicolumn{2}{|c|}{11 месяцев } & \multicolumn{2}{|c|}{12 месяцев } \\
\hline $\begin{array}{l}\text { телки } \\
\text { бычки }\end{array}$ & $\begin{array}{l}754 \\
567\end{array}$ & $\mid \begin{array}{l}439-1021 \\
596-942\end{array}$ & $\begin{array}{l}705 \\
536\end{array}$ & & $\begin{array}{l}792 \\
558\end{array}$ & $\begin{array}{l}386-994 \\
574-908\end{array}$ & $\begin{array}{l}604 \\
498\end{array}$ & $\begin{array}{l}418-955 \\
428-948\end{array}$ \\
\hline $\begin{array}{l}\text { II группа } \\
\text { телки } \\
\text { бычки }\end{array}$ & $\begin{array}{l}630 \\
540\end{array}$ & $\begin{array}{l}486-766 \\
433-753\end{array}$ & $\begin{array}{l}755 \\
783\end{array}$ & $\begin{array}{l}483-979 \\
516-1007\end{array}$ & $\begin{array}{l}618 \\
993\end{array}$ & $\begin{array}{l}309-969 \\
838-1091\end{array}$ & $\begin{array}{l}565 \\
823\end{array}$ & $\begin{array}{l}351-797 \\
721-985\end{array}$ \\
\hline
\end{tabular}


крутыми рывками, скачками. Ритмичность роста впервые была подробно изучена В. И. Федоровым $\left({ }^{5}\right)$.

Молюдняк первой группы к 12 -месячному возрасту по росту превышал предусмотренные в плане показатели, рост же молодняка второй группы отставал от плана. Достигнутый живой вес у обеих групп животных превышал требования бонитировки класса элита-рекорд у телок первой группы на $23 \%$, у бычков первой группы на $13 \%$, у телок второй группы

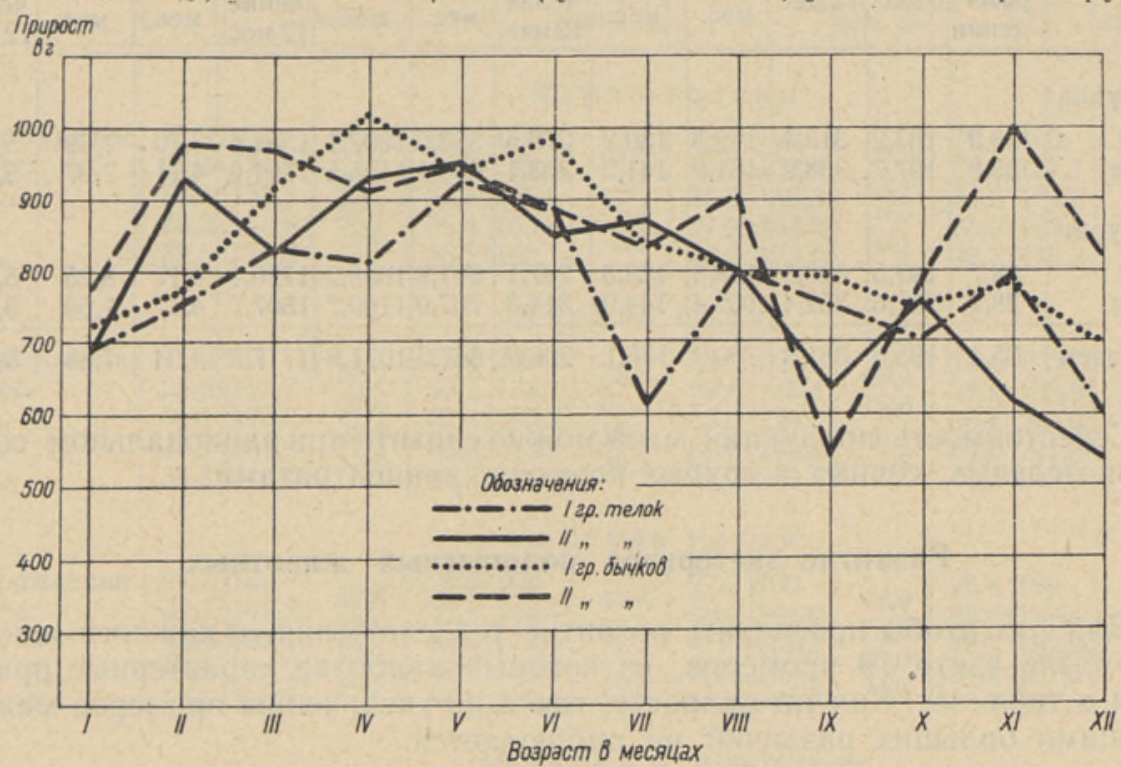

Рис. 3. Среднесуточный прирост в г по месяцам до годовалого возраста

на $26 \%$ и у бычков второй группы на $17 \%$. Небольшая разница между группами в приросте обусловлена, повидимому, тем обстоятельством, что животные обеих групп съедали питательные вещества до физиологического предела и того же предела достигал и суточный прирост молодняка в данных условиях содержания и ухода.

Қак видно, тип кормления молодняка второй группы является экономически невыгодным, так как лишние 200 кг цельного молока, 300 кг обрата и 190 кг концентрированных кормов не давали по привесам сколько-нибудь заметного эффекта.

В связи с полученными нами результатами необходимо упомянуть об опыте совхоза «Караваево» $\left({ }^{4}\right)$. Как известно, в этом совхозе в течение многих лет телятам спаивали по 600-650 кг цельного молока и 2500 кг обрата. При переходе во время войны к более низким нормам кормления - до 420-450 кг цельного молока -- суточные привесы молодняка благодаря высокому мастерству телятниц остались на высоком уровне.

Что касается воцроса об оплачиваемости корма привесом, то, как видно из 'табл. 9, наиболее экономно выращивался молодняк первой группы до 6-месячного возраста. Во втором полугодии такое положение отмечается только в отношении телок. Бычки, повидимому, склонны более экономно использовать увеличивающееся в рационе количество грубых и сочных кормов. Необходимо при этом отметить, что во втором полугодии затраты кормовых единиц на 1 кг привеса превышают соответствующие затраты в первом полугодии у телок на $103 \%$ и у бычков на $86 \%$. Это обстоятельство важно учитывать при выращивании бычков для забоя. 


\begin{tabular}{|c|c|c|c|c|c|c|c|c|c|c|c|c|}
\hline \multirow{2}{*}{$\begin{array}{c}\text { Подопыт- } \\
\text { ные } \\
\text { группы }\end{array}$} & \multicolumn{3}{|c|}{$\begin{array}{c}\text { Средний живой } \\
\text { вес в кг }\end{array}$} & \multicolumn{3}{|c|}{$\begin{array}{c}\text { Увеличение живого } \\
\text { веса в кг }\end{array}$} & \multicolumn{3}{|c|}{$\begin{array}{c}\text { Сумма затраченны X } \\
\text { кормовых еднниц } \\
\text { в кг }\end{array}$} & \multicolumn{3}{|c|}{$\begin{array}{c}\text { Затрачено кормо- } \\
\text { вых единиц на } 1 \text { кг } \\
\text { привеса }\end{array}$} \\
\hline & $\begin{array}{l}\text { При } \\
\text { рож- } \\
\text { дении }\end{array}$ & 6 мес. & $12 \mathrm{мес}$ & $\begin{array}{l}\text { До } 6 \\
\text { мес. }\end{array}$ & $\begin{array}{l}7-12 \\
\text { мес. }\end{array}$ & $\left|\begin{array}{c}\text { В те- } \\
\text { чение } \\
12 \text { мес. }\end{array}\right|$ & $\begin{array}{l}\text { До } 6 \\
\text { мес. }\end{array}$ & $\begin{array}{r}7-12 \\
\text { мес. }\end{array}$ & \begin{tabular}{|} 
В те- \\
чение \\
12 мес.
\end{tabular} & $\begin{array}{l}\text { До } 6 \\
\text { мес. }\end{array}$ & $\left|\begin{array}{c}7-12 \\
\text { мес. }\end{array}\right|$ & \begin{tabular}{|l} 
В те- \\
чение \\
12 мес.
\end{tabular} \\
\hline $\begin{array}{l}\text { I группа } \\
\text { телки } \\
\text { бычки }\end{array}$ & $\begin{array}{l}33,9 \\
35,8\end{array}$ & $\begin{array}{l}183,2 \\
197,7\end{array}$ & $\begin{array}{l}313,4 \\
338,9\end{array}$ & $\begin{array}{l}149,3 \\
161,9\end{array}$ & $\begin{array}{l}130,2 \\
141,2\end{array}$ & $\begin{array}{l}279,5 \\
303,1\end{array}$ & $\begin{array}{l}553,0 \\
666,1\end{array}$ & $\begin{array}{l}1002,1 \\
1125,5\end{array}$ & $\begin{array}{l}1551,6 \\
1791,6\end{array}$ & $\begin{array}{l}3,70 \\
4,11\end{array}$ & $\begin{array}{l}7,69 \\
7,97\end{array}$ & $\begin{array}{l}5,55 \\
5,91\end{array}$ \\
\hline $\begin{array}{l}\text { II группа } \\
\text { телки } \\
\text { бычки }\end{array}$ & $\begin{array}{l}33,7 \\
38,2\end{array}$ & $\begin{array}{l}192,5 \\
207,6\end{array}$ & $\begin{array}{l}320,8 \\
352,4 \\
\end{array}$ & \begin{tabular}{|}
158,8 \\
169,4 \\
\end{tabular} & \begin{tabular}{|l|}
128,3 \\
144,9 \\
\end{tabular} & $\begin{array}{l}287,1 \\
314,3\end{array}$ & $\begin{array}{l}661,9 \\
707,0\end{array} \mid$ & $\begin{array}{l}1058,2 \\
1100,7\end{array}$ & $\begin{array}{l}1720,1 \\
1807,7\end{array}$ & $\begin{array}{l}4,17 \\
4,17\end{array}$ & $\begin{array}{l}8,25 \\
7,60\end{array}$ & $\begin{array}{l}5,99 \\
5,75\end{array}$ \\
\hline В среднем & 35,4 & 195,3 & 331,3 & $|159,9|$ & 136,1 & 296,0 & $|647,0|$ & 1071,6 & $\mid 1717,8$ & 4,04 & 7,88 & 5,80 \\
\hline
\end{tabular}

Себестоимость продукции мяса можно снизить при ращиональном сочетании зеленых, сочных и грубых кормов с концентратами.

\section{Развитие экстерьера подопытных животных}

Для тогочтобы проследить развитие телосложения, от каждого животного было взято, 19 промеров, из которых наиболее характерные приведены в табл. 10. Как по приросту, так и по увеличению промеров между группами больших различий не наблюдается.

Т а бл иц а 10

Сравнительные данные о развитии телосложения подопытного молодняка

\begin{tabular}{|c|c|c|c|c|c|c|c|c|c|c|c|c|}
\hline \multirow[b]{3}{*}{ Bоз р а с т } & \multicolumn{6}{|c|}{$\mathrm{T}$ е } & \multicolumn{6}{|c|}{ Б } \\
\hline & \multicolumn{3}{|c|}{ I группа } & \multicolumn{3}{|c|}{ II rрyпnа } & \multicolumn{3}{|c|}{ I группа } & \multicolumn{3}{|c|}{ II групла } \\
\hline & cM & $\%$ & \begin{tabular}{|c|} 
Ско- \\
рость \\
уве- \\
лич. \%
\end{tabular} & cM & $\%$ & \begin{tabular}{|c|} 
Ско- \\
рость \\
уве- \\
лич. \%
\end{tabular} & cM & $\%$ & $\mid \begin{array}{c}\text { Ско- } \\
\text { рость } \\
\text { уве- } \\
\text { лич. \% }\end{array}$ & cM & $\%$ & $\begin{array}{c}\text { Ско- } \\
\text { рость } \\
\text { уве- } \\
\text { лич. \% }\end{array}$ \\
\hline \multirow{3}{*}{$\begin{array}{l}\text { При рождевии } \\
3 \text { мес. } \\
6 \text { : } \\
y \\
12:\end{array}$} & \multicolumn{12}{|c|}{ Высота в холке } \\
\hline & $\begin{array}{r}70,6 \\
90,5 \\
98,4 \\
104,0 \\
114,3\end{array}$ & $\begin{array}{l}100 \\
128,2 \\
139,4 \\
147,3 \\
161,9\end{array}$ & $\begin{array}{r}28,2 \\
11,2 \\
7,9 \\
14,6\end{array}$ & $\begin{array}{r}71,3 \\
89,8 \\
100,5 \\
108,6 \\
114,9\end{array}$ & $\begin{array}{l}100 \\
125,9 \\
147,3 \\
152,3 \\
161,2\end{array}$ & $\begin{array}{r}25,9 \\
21,4 \\
5,0 \\
8,9\end{array}$ & $\mid \begin{array}{r}71,9 \\
90,6 \\
100,0 \\
111,0 \\
120,2\end{array}$ & $\begin{array}{l}100 \\
126,0 \\
139,1 \\
154,4 \\
167,2\end{array}$ & $\begin{array}{l}26,0 \\
13,1 \\
15,3 \\
12,8\end{array}$ & $\begin{array}{r}71,6 \\
92,1 \\
100,6 \\
106,0 \\
120,0\end{array}$ & $\begin{array}{l}100 \\
128,6 \\
140,5 \\
148,0 \\
167,6\end{array}$ & $\begin{array}{r}28,6 \\
11,9 \\
7,5 \\
19,6\end{array}$ \\
\hline & \multicolumn{12}{|c|}{ Высота в крестце } \\
\hline $\begin{array}{l}\text { При рождени и } \\
3 \text { мес. } \\
6 \\
9 \\
12\end{array}$ & $\begin{array}{r}75,1 \\
93,2 \\
101,7 \\
110,3 \\
119,8\end{array}$ & $\begin{array}{l}100 \\
124,1 \\
135,4 \\
146,9 \\
159,5\end{array}$ & $\begin{array}{l}24,1 \\
11,3 \\
11,5 \\
12,6\end{array}$ & $\begin{array}{r}73,0 \\
95,3 \\
103,1 \\
113,9 \\
117,8\end{array}$ & $\mid \begin{array}{l}100 \\
130,6 \\
141,2 \\
156,0 \\
161,4\end{array}$ & $\begin{array}{r}30,6 \\
10,6 \\
14,8 \\
5,4\end{array}$ & $\mid \begin{array}{r}74,6 \\
94,1 \\
105,0 \\
113,8 \\
123,9\end{array}$ & $\begin{array}{l}100 \\
126,1 \\
140,8 \\
152,6 \\
166,1\end{array}$ & $\begin{array}{l}26,1 \\
14,7 \\
11,8 \\
13,5\end{array}$ & $\begin{array}{r}75,3 \\
96,2 \\
105,5 \\
113,8 \\
122,2\end{array}$ & $\begin{array}{l}100 \\
127,8 \\
140,1 \\
151,1 \\
162,3\end{array}$ & $\begin{array}{l}27,8 \\
12,3 \\
11,0 \\
11,2\end{array}$ \\
\hline \multicolumn{13}{|c|}{ Косая длина туловища } \\
\hline $\begin{array}{l}\text { При рождении } \\
3 \text { мес. } \\
6 \\
9 \\
12\end{array}$ & $\mid \begin{array}{r}66,0 \\
100,0 \\
114,8 \\
120,1 \\
130,0\end{array}$ & $\begin{array}{l}100 \\
151,5 \\
173,9 \\
182,0 \\
197,0\end{array}$ & $\begin{array}{r}51,5 \\
22,4 \\
8,1 \\
15,0\end{array}$ & $\mid \begin{array}{r}67,9 \\
103,5 \\
119,4 \\
129,9 \\
130,2\end{array}$ & $\begin{array}{l}100 \\
152,4 \\
175,9 \\
191,3 \\
191,8\end{array}$ & $\begin{array}{r}52,4 \\
23,5 \\
15,4 \\
0,5\end{array}$ & $\begin{array}{r}69,6 \\
99,3 \\
114,1 \\
125,1 \\
142,7\end{array}$ & $\begin{array}{l}100 \\
142,7 \\
163,9 \\
179,7 \\
205,0\end{array}$ & $\begin{array}{l}42,7 \\
21,2 \\
15,8 \\
25,3\end{array}$ & $\mid \begin{array}{r}69,6 \\
104,7 \\
120,3 \\
127,0 \\
140,2\end{array}$ & $\mid \begin{array}{l}100 \\
150,4 \\
172,8 \\
182,5 \\
201,4\end{array}$ & $\begin{array}{r}50,4 \\
22,4 \\
9,7 \\
18,9\end{array}$ \\
\hline
\end{tabular}


Наиболее медленно у телок и бычков увеличивается обхват пясти, за которым по возрастающей скорости следует высота в крестце, высота в холке и т. д.

Почти все части тела растут с бо́льшей скоростью в возрасте от рождения до 3 месяцев. Исключения наблюдаются по ширине груди. Самый энергичный рост груди в ширину у телок второй группы и у бычков обеих групп происходит в возрасте от 3 до 6 месяцев жизни. В большинстве случаев самая низкая энергия роста наблюдается в возрасте от 6 до 9 месяцев, после чего следует новое возрастание скорости роста у молодняка до 12 месяцев. Но рост в этот период далеко отстает от энергии роста животных до 3-месячного возраста.

Сравнение коэффициентов роста экстерьерных промеров (табл. 11) показывает, что в постэмбриональном периоде самым интенсивным ростом отличаются промеры по ширине, особенно ширина груди и ширина

Т а бли ца 11

Коэффициенты изменения экстерьерных промеров подопытного молодняка

(Увеличение промеров по огношению к соответствующим промерам в суточном возрасте животных)

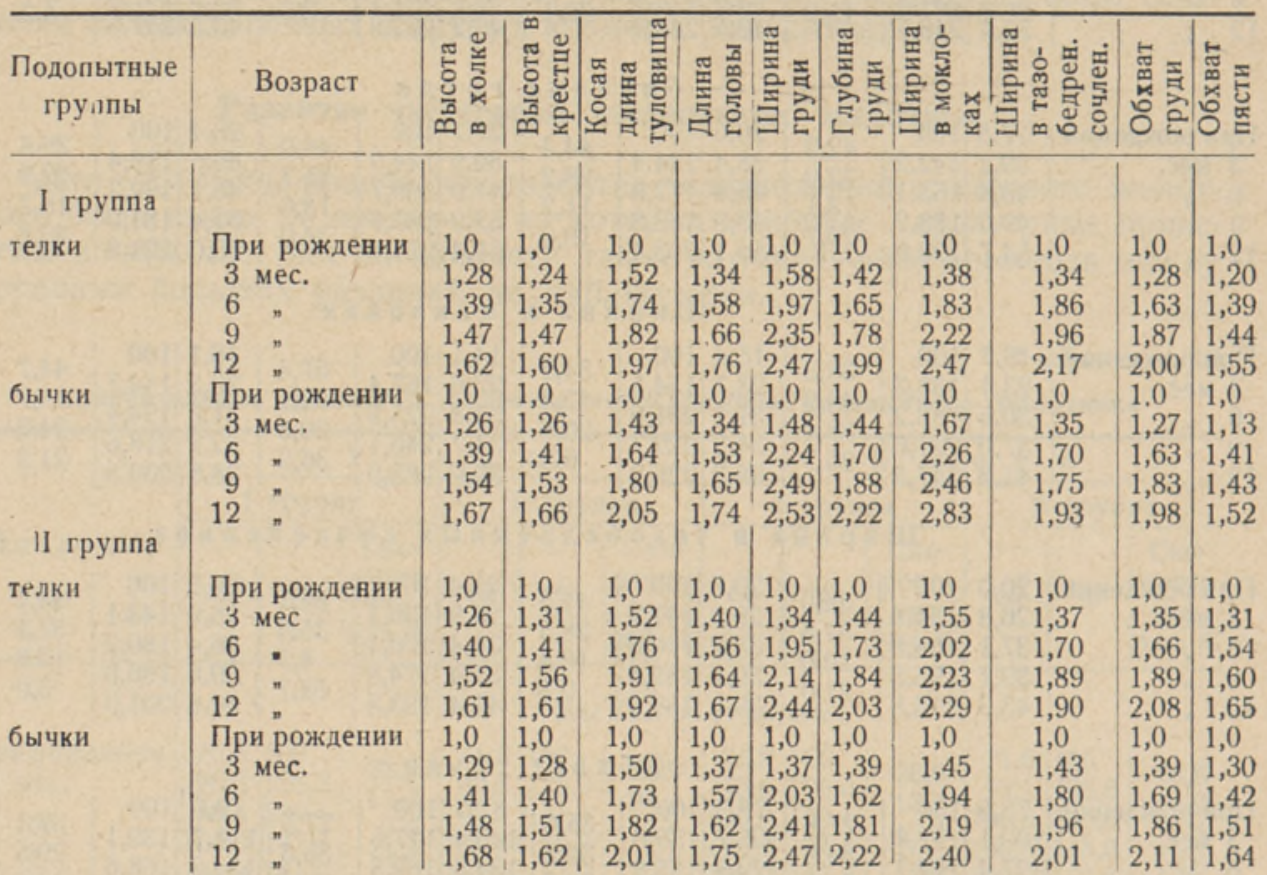

в моклоках. К годовалому возрасту ширина груди по сравнению с шириной при рождении увеличивается в два с половиной раза. Обхват груди, косая длина туловища, ширина в тазобедренных сочленениях к годовалому возрасту увеличиваются в два раза. Самым низким темпом роста отличаются высотные промеры и обхват пясти. Коэффициенты роста показывают со всей ясностью, что с помощью интенсивного кормления в первом году жизни можно выращивать животных с компактным телосложением, развитой мускулатурой и крепкой конституцией (рис. 4 и 5). 


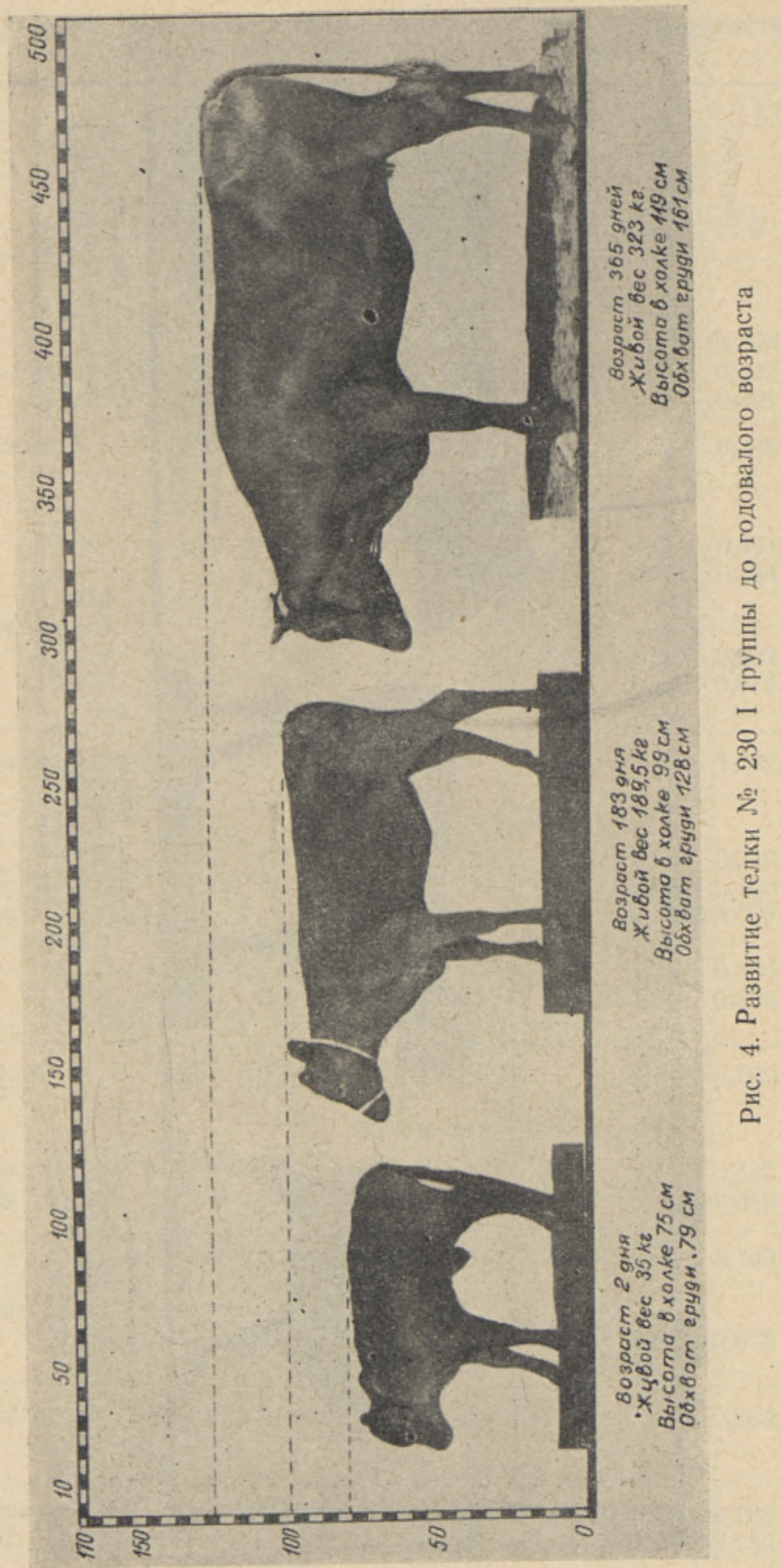




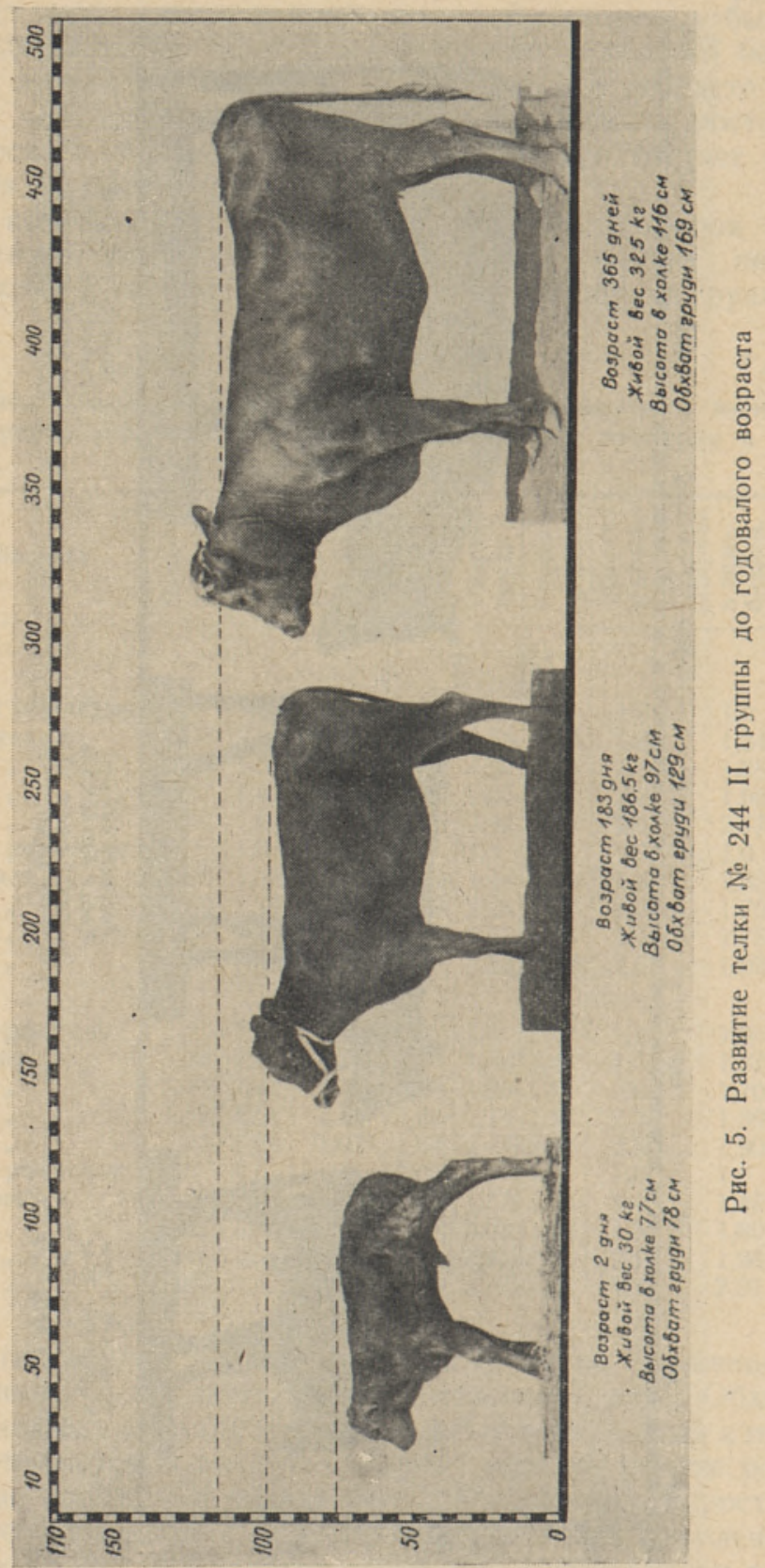


Усвояемость питательных веществ кормовых рационов

Для выяснения эффективности использования питательных веществ при разных уровнях и типах кормления был проведен ряд опытов по изу-

Т а бл и ц а 12

Суточные рационы при проведении опытов по переваримости и по обмену азота, кальция и фосфора

\begin{tabular}{|c|c|c|c|c|c|c|c|c|c|c|}
\hline \multirow{2}{*}{ Корма } & \multicolumn{5}{|c|}{ I r p y n n a } & \multicolumn{5}{|c|}{ II группа } \\
\hline & 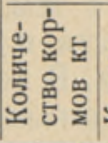 & 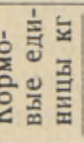 & 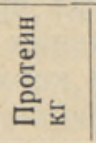 & $\bar{U}$ & 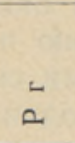 & 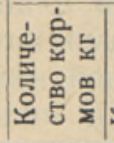 & 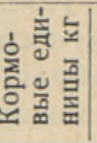 & 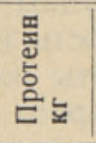 & ๘̋ & a. \\
\hline & \multicolumn{10}{|c|}{ Первы й } \\
\hline $\begin{array}{l}\text { Молоко } \\
\text { Сено клеверное } \\
\text { Овсяная мука }\end{array}$ & $\begin{array}{l}8,0 \\
0,100 \\
0,050\end{array}$ & $\begin{array}{l}2,50 \\
0,03 \\
0,03\end{array}$ & $\begin{array}{l}0,235 \\
0,003 \\
0,002\end{array}$ & $\begin{array}{r}10 \\
1 \\
-\end{array}$ & $\frac{8}{-}$ & $\begin{array}{c}12,0 \\
0,050 \\
0,020\end{array}$ & $\begin{array}{l}3,67 \\
0,01 \\
0,01\end{array}$ & $\begin{array}{l}0,396 \\
0,001 \\
0,001\end{array}$ & $\frac{16}{-}$ & $\frac{13}{-}$ \\
\hline Bcero & - & 2,56 & 0,240 & 11 & 8 & 1. & 3,69 & 0,398 & 16 & 13 \\
\hline $\begin{array}{l}\text { Обрат } \\
\text { Зеленая трава } \\
\text { Сено клеверное } \\
\text { Свекла кормовая } \\
\text { Овсяная мука } \\
\text { Жмых льняной } \\
\text { Костяная мука }\end{array}$ & $\begin{array}{l}10 \\
0, \overline{4} \\
0,5 \\
0,4 \\
0,4 \\
0,03\end{array}$ & $\begin{array}{l}1,25 \\
0,16 \\
0,05 \\
0,36 \\
0,40 \\
-\end{array}$ & $\begin{array}{l}0,240 \\
\overline{0} \\
0,013 \\
0,005 \\
0,025 \\
0,104 \\
-\end{array}$ & $\begin{array}{l}\text { B T } \\
13 \\
\frac{4}{4} \\
1 \\
2 \\
6\end{array}$ & $\begin{array}{r}\text { ро й } \\
-\frac{11}{1} \\
-\frac{1}{2} \\
4 \\
2\end{array}$ & $\begin{array}{l}\text { пе р и с } \\
\begin{array}{|c|}12,0 \\
2,3 \\
- \\
\overline{-} \\
0,3 \\
0,3 \\
0,03\end{array}\end{array}$ & $\begin{array}{l}1,69 \\
0,88 \\
- \\
\overline{0,27} \\
0,30 \\
-\end{array}$ & $\begin{array}{l}0,441 \\
0,194 \\
-\overline{0} \\
0,019 \\
0,078\end{array}$ & $\begin{array}{r}17 \\
4 \\
- \\
- \\
-1 \\
6\end{array}$ & $\begin{array}{r}14 \\
2 \\
- \\
-1 \\
3 \\
2\end{array}$ \\
\hline Bcero & - & 2,22 & 0,387 & 26 & 20 & - & 3,14 & 0,732 & 28 & 22 \\
\hline $\begin{array}{l}\text { Обрат } \\
\text { Сено клеверное } \\
\text { Свекла кормовая } \\
\text { Ботва } \\
\text { Овсяная мука } \\
\text { Жмых льняной } \\
\text { Костяная мука }\end{array}$ & $\begin{array}{l}4,0 \\
4,0 \\
1,0 \\
1,0 \\
1,0 \\
0,03\end{array}$ & $\begin{array}{l}0,53 \\
2,00 \\
- \\
0,06 \\
1,00 \\
1,00 \\
-\end{array}$ & $\begin{array}{l}0,115 \\
0,174 \\
-\overline{0} \\
0,094 \\
0,260 \\
-\end{array}$ & $\begin{array}{r}\mathrm{T} \\
5 \\
36 \\
- \\
2 \\
2 \\
4 \\
6\end{array}$ & $\begin{array}{l}\text { е и и й } \\
5 \\
8 \\
- \\
- \\
4 \\
10 \\
2\end{array}$ & $\begin{array}{c}\text { п е р и } \\
\left|\begin{array}{c}8,0 \\
2,3 \\
3,0 \\
- \\
1,25 \\
1,25 \\
0,10\end{array}\right|\end{array}$ & $\begin{array}{l}0 \text { д } \\
0,86 \\
1,15 \\
0,22 \\
- \\
1,25 \\
1,25 \\
-\end{array}$ & $\begin{array}{l}0,249 \\
0,100 \\
0,037 \\
\overline{0}, 085 \\
0,325 \\
-\end{array}$ & $\begin{array}{r}14 \\
21 \\
- \\
- \\
2 \\
5 \\
20\end{array}$ & $\begin{array}{r}7 \\
4 \\
- \\
-5 \\
12 \\
5\end{array}$ \\
\hline Bcero & \multicolumn{10}{|c|}{ Четвертый период } \\
\hline $\begin{array}{l}\text { Сено тнмофеечное } \\
\text { Свекла кормовая } \\
\text { Картофель } \\
\text { Овсяная мука } \\
\text { Жмых соевый } \\
\text { Жмых подсолнеч- } \\
\text { ный } \\
\text { Костяная мука }\end{array}$ & $\begin{array}{l}4,5 \\
7,0 \\
3,0 \\
1,0 \\
1,0 \\
0, \overline{1} \\
\end{array}$ & $\begin{array}{l}1,96 \\
0,69 \\
0,97 \\
1,04 \\
1,37 \\
- \\
-\end{array}$ & $\begin{array}{l}0,178 \\
0,069 \\
0,044 \\
0,069 \\
0,438 \\
- \\
-\end{array}$ & $\begin{array}{r}23 \\
1 \\
1 \\
2 \\
3 \\
- \\
29\end{array}$ & $\begin{array}{r}9 \\
2 \\
2 \\
4 \\
7 \\
-14 \\
\end{array}$ & $\left|\begin{array}{c}3,6 \\
6,0 \\
1,5 \\
- \\
1,5 \\
0,1\end{array}\right|$ & $\begin{array}{l}1,61 \\
0,59 \\
\overline{1,56} \\
- \\
1,63 \\
-\end{array}$ & $\begin{array}{c}0,147 \\
0,059 \\
\overline{0}, 103 \\
- \\
0,675 \\
-\end{array}$ & $\begin{array}{r}18 \\
1 \\
- \\
- \\
- \\
4 \\
29\end{array}$ & $\begin{array}{l}7 \\
2 \\
-6 \\
-\end{array}$ \\
\hline Bcero & - & \multicolumn{8}{|c|}{. Пятый период } & 46 \\
\hline $\begin{array}{l}\text { Сено тимофеечное } \\
\text { Свекла кормовая } \\
\text { Картофель } \\
\text { Овсяная мука } \\
\text { Жмых подсолнеч- } \\
\text { ный }\end{array}$ & $\begin{array}{r}5,0 \\
10,0 \\
4,0 \\
0,5 \\
0,5\end{array}$ & $\begin{array}{l}2,50 \\
0,74 \\
1,25 \\
0,48 \\
0,54\end{array}$ & $\begin{array}{l}0,258 \\
0,124 \\
0,054 \\
0,033 \\
0,224\end{array}$ & $\begin{array}{r}42 \\
3 \\
1 \\
1 \\
2\end{array}$ & $\begin{array}{r}10 \\
3 \\
2 \\
2 \\
6\end{array}$ & $\left|\begin{array}{r}4,0 \\
10,0 \\
\overline{1,5} \\
1,5\end{array}\right|$ & $\begin{array}{l}1,82 \\
0,74 \\
1,50 \\
1,63\end{array}$ & $\begin{array}{l}0,186 \\
0,138 \\
\overline{0}, 110 \\
0,675\end{array}$ & $\begin{array}{r}31 \\
3 \\
3 \\
4\end{array}$ & $\begin{array}{r}7 \\
4 \\
4 \\
17\end{array}$ \\
\hline Костяная мука & 0,1 & 5,51 & $\frac{-}{0,693}$ & $\frac{29}{78}$ & $\frac{14}{37}$ & 0,1 & $\frac{-}{5,69}$ & $\frac{-}{1,109}$ & $\frac{29}{70}$ & $\frac{14}{46}$ \\
\hline
\end{tabular}

6 Tead. Akad. toimetised 4 
чению переваримости кормовых рационов и по обмену азота, кальция, фосфора и каротина в различные периоды роста и развития животных. Были взяты следуюшие периоды: I период-в возрасте 1 месяца, II период - в возрасте 3 месяцев, III период - в возрасте 6 месяцев. IV пернод - в возрасте 9 месяцев, V период - в возрасте 12 месяцев. Опыты проводились по методике, разработанной Всесоюзным научноисследовательским институтом животноводства.

Физиологические исследования были проведены на 3 животных из каждой группы. Такой план опытов был принят с тем, чтобы изучить переваримость и ассимиляцию питательных веществ в самые характерные моменты избранной нами системы кормления. В конце первого и в начале второго месяца молодняку выпоили максимальные количества цельного молока, а именно, животным первой группы по 8 кг, второй группы по 12 кг в день. В конце третьего месяца все животные получали максимальные дачи обрата - первая группа $10 \mathrm{kr}$, вторая 12 кг в день. В 6-месячном возрасте животные получали рационы, почти равноценные по количеству и качеству, в 9-12-месячном возрасте животных кормили по рационам различного типа (табл. 12). В IV периоде животные первой группы не были в состоянии полностью съедать предусмотренные рационы.

В табл. 13 приведены коэффициенты переваримости питательных веществ в кормовых рационах. Более,высокая переваримость кормов животными второй группы в течение первых трех периодов объясняется содержанием в их рационе большого количества легко переваримых кор-

Т а б ли ц а 13

Коэффициенты переваримости питательных веществ корма

\begin{tabular}{|c|c|c|c|c|c|c|c|c|c|c|c|}
\hline $\begin{array}{c}\text { Периоды } \\
\text { опыта }\end{array}$ & 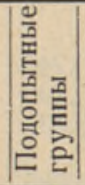 & 鰙 & 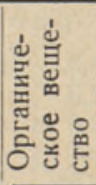 & 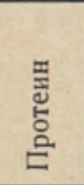 & 产 & 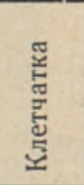 & 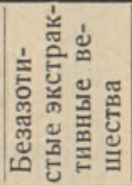 & 占 & 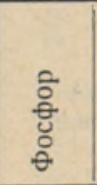 & 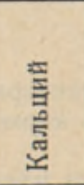 & 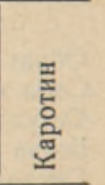 \\
\hline Dn & $\begin{array}{l}\text { I } \\
\text { II }\end{array}$ & $\begin{array}{l}89,98 \\
92,24\end{array}$ & $\begin{array}{l}91,00 \\
94,80\end{array}$ & $\begin{array}{l}86,86 \\
93,07\end{array}$ & $\begin{array}{l}93,34 \\
9477\end{array}$ & 46,12 & $\begin{array}{l}94,26 \\
96,24\end{array}$ & & $\begin{array}{l}94,57 \\
94,88\end{array}$ & $\begin{array}{l}75,18 \\
85,68\end{array}$ & $\begin{array}{l}38,03 \\
40,00\end{array}$ \\
\hline Второй & $\begin{array}{l}\text { I } \\
\text { II }\end{array}$ & $\begin{array}{l}72,05 \\
80,56\end{array}$ & $\begin{array}{l}73,39 \\
82,12\end{array}$ & $\begin{array}{l}81,67 \\
85,13\end{array}$ & $\begin{array}{l}68,12 \\
68,01\end{array}$ & $\begin{array}{l}52,23 \\
67,14\end{array}$ & $\begin{array}{l}75,69 \\
84,58\end{array}$ & & $\begin{array}{l}76,32 \\
61,70\end{array}$ & $\begin{array}{l}46,89 \\
43,93\end{array}$ & $\begin{array}{l}45,87 \\
89,28\end{array}$ \\
\hline & $\begin{array}{l}\text { I } \\
\text { II }\end{array}$ & $\begin{array}{l}68,88 \\
73,06\end{array}$ & $\begin{array}{l}70,82 \\
74,67\end{array}$ & & & & $\begin{array}{l}76,73 \\
76,69\end{array}$ & & & & $\begin{array}{l}91,11 \\
91,20\end{array}$ \\
\hline Четвертый & I & $\begin{array}{l}72,37 \\
72,97\end{array}$ & $\begin{array}{l}74,20 \\
74,82\end{array}$ & & & & & & & & $\begin{array}{r}100,00 \\
96,81\end{array}$ \\
\hline Пятый & $\begin{array}{l}\text { I } \\
\text { II }\end{array}$ & $\begin{array}{l}74,86 \\
62,32\end{array}$ & $\begin{array}{l}76,19 \\
64,39\end{array}$ & $\begin{array}{l}72,28 \\
72,87\end{array}$ & $\begin{array}{l}43,04 \\
52,39\end{array}$ & $\begin{array}{l}67,32 \\
42,59\end{array}$ & & & $\begin{array}{l}57,83 \\
36,96\end{array}$ & $\begin{array}{l}58,86 \\
40,46\end{array}$ & \\
\hline
\end{tabular}

мов (цельное молоко, обрат). При этом установлено, что 12 кг цельного молока телята выпивали со значительным напряжением. Но в наших опытах, которые проводились на обильных дачах кормов, мы не отметили никакой депрессии в переваримости и ассимиляции питательных веществ. Отметим, что Л. И. Дракин $\left({ }^{2}\right)$ на основании результатов своих опытов пришел к выводу, что обильные дачи молока снижают переваримость питательных веществ. По приведенным в табл. 14 данным нельзя с уверенностью сказать, чтобы в кишечнике животных происходили какие-либо неблагоприятные процессы (гниение) из-за применения высоких дач молочных кормов. Определение содержания ацетона и белка в моче дало 
Некоторые показатели свойств мочи подопытных животных

\begin{tabular}{c|c|c|c|c}
\hline $\begin{array}{c}\text { Периоды } \\
\text { опыта }\end{array}$ & $\begin{array}{c}\text { Подопытные } \\
\text { группы }\end{array}$ & Индикан мг л & $\mathrm{pH}$ & $\begin{array}{c}\text { Удельный } \\
\text { вес }\end{array}$ \\
\cline { 2 - 5 } I & I & $0,8(0,3-0,9)$ & 6,65 & 1,0071 \\
& II & $2,5(1,7-3,7)$ & 8,65 & 1,0081 \\
II & I & $10,3(9,9-10,5)$ & 7,99 & 1,0197 \\
& II & $6,3(5,4-8,1)$ & 8,40 & 1,0174 \\
III & I & $2,7(2,0-3,2)$ & 8,28 & 1,0230 \\
& II & $4,5(3,2-5,6)$ & 8,62 & 1,0217
\end{tabular}

отрицательные результаты. Низкие коэффициенты переваримости в пятом периоде у животных второй группы объясняются, с одной стороны, пониженным содержанием сочных кормов, а с другой - слишком большим количеством протеина в рационе.

Результаты контрольного забоя показали, что животные первой группы имели несколько более объемистый желудок и более длинный кишечный канал. Это обстоятельство не могло не оказать влияния на переваримость кормов в годовалом возрасте.

Параллельно с перевариванием корма идет его усвоение организмом (табл. $15,16,17)$. На основании данных относительно отложения

Обмен азота у телят

Т а бл и ц а 15

\begin{tabular}{|c|c|c|c|c|c|c|c|c|c|c|c|c|}
\hline \multirow[b]{2}{*}{$\begin{array}{c}\text { Периоды } \\
\text { опыта }\end{array}$} & \multirow[b]{2}{*}{ 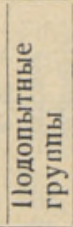 } & \multirow[b]{2}{*}{ 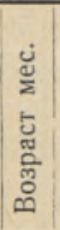 } & \multirow[b]{2}{*}{ 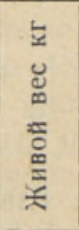 } & \multirow{2}{*}{ 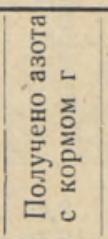 } & \multicolumn{3}{|c|}{ Выделено азота г } & \multirow[b]{2}{*}{ 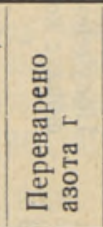 } & \multicolumn{4}{|c|}{ Отложено азота } \\
\hline & & & & & 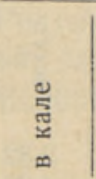 & $\begin{array}{l}\frac{0}{2} \\
\frac{0}{2} \\
\infty\end{array}$ & 일 & & 㐫 & 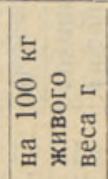 & 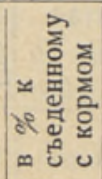 & 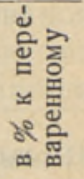 \\
\hline กриน" & $\begin{array}{l}\text { I } \\
\text { II }\end{array}$ & $\begin{array}{c}1 \\
1,2\end{array}$ & $\begin{array}{l}52,2 \\
64,5\end{array}$ & $\begin{array}{l}41,16 \\
59,61\end{array}$ & $\begin{array}{l}5,31 \\
4,52\end{array}$ & & $\begin{array}{l}17,94 \\
20,17\end{array}$ & $\begin{array}{l}35,85 \\
55,09\end{array}$ & $\begin{array}{l}23,22 \\
39,44\end{array}$ & $\begin{array}{l}44,4 \\
61,1\end{array}$ & $\begin{array}{l}56,61 \\
66,16\end{array}$ & $\begin{array}{l}67,9 \\
71,5\end{array}$ \\
\hline , s. & II & $\begin{array}{l}3 \\
3\end{array}$ & $\begin{array}{r}98,8 \\
112,8\end{array}$ & $\begin{array}{r}95,90 \\
124,86\end{array}$ & & $\begin{array}{l}37,40 \\
47,77\end{array}$ & & $\begin{array}{r}79,68 \\
105,84\end{array}$ & & $\begin{array}{l}42,8 \\
51,5\end{array}$ & & \\
\hline & I & $\begin{array}{l}6 \\
6\end{array}$ & $\begin{array}{l}184,8 \\
199,0\end{array}$ & $\begin{array}{l}139,76 \\
186,61\end{array}$ & $\begin{array}{l}40,05 \\
39,91\end{array}$ & $\begin{array}{r}68,54 \\
107,59\end{array}$ & $\begin{array}{l}108,59 \\
147,50\end{array}$ & $\begin{array}{r}99,71 \\
146,70\end{array}$ & & $\begin{array}{l}16,9 \\
19,7\end{array}$ & $\begin{array}{l}22,30 \\
20,96\end{array}$ & $\begin{array}{l}31,26 \\
26,66\end{array}$ \\
\hline 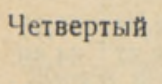 & $\begin{array}{l}\text { I } \\
\text { II }\end{array}$ & $\begin{array}{l}9 \\
9\end{array}$ & $\begin{array}{l}249,0 \\
262,0\end{array}$ & $\begin{array}{l}16221 \\
193,90\end{array}$ & $\begin{array}{l}44,97 \\
44,89\end{array}$ & $\begin{array}{r}94,05 \\
112,87\end{array}$ & $\begin{array}{l}139,02 \\
157,76\end{array}$ & $\begin{array}{l}117, \\
149,\end{array}$ & & $\begin{array}{r}9,3 \\
13,8\end{array}$ & & \\
\hline ятый & I & $\begin{array}{l}12 \\
12\end{array}$ & $\begin{array}{l}306,5 \\
335,3\end{array}$ & $\begin{array}{r}153,35 \\
234,47\end{array}$ & $\begin{array}{l}42,74 \\
63,58\end{array}$ & & & $\begin{array}{l}110,61 \\
170,89\end{array}$ & $\begin{array}{l}38,89 \\
25,08\end{array}$ & $\begin{array}{r}12,7 \\
7,5\end{array}$ & & $\begin{array}{l}35,68 \\
14,16\end{array}$ \\
\hline
\end{tabular}

азота, кальция и фосфора в теле животных устанавливается определенная закономерность образования мышечной ткани и скелета растущего молодняка (рис. 6). Характерно, что отложения кальция и фосфора в организме животных до 12-месячного возраста не претерпевают таких больших изменений, как отложения азота. К концу первого года среднесуточное (среднее по двум группам) отложение азота составляло только $19,13 \%$ (на 100 кг живого веса), а кальция и фосфора, соответственно, $53,35 \%$ и $38,29 \%$ количества этих веществ, отложенных в первом месяце жизни. 
Обмен кальция у телят

\begin{tabular}{|c|c|c|c|c|c|c|c|c|c|c|c|c|}
\hline \multirow[b]{2}{*}{$\begin{array}{c}\text { Периоды } \\
\text { опыта }\end{array}$} & \multirow[b]{2}{*}{ 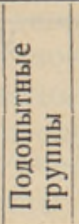 } & \multirow[b]{2}{*}{ 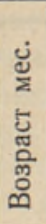 } & \multirow[b]{2}{*}{ 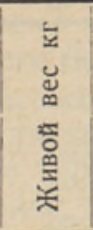 } & \multirow{2}{*}{ 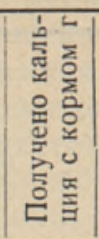 } & \multicolumn{3}{|c|}{ Выделено кальшия г } & \multirow[b]{2}{*}{ 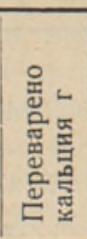 } & \multicolumn{4}{|c|}{ Отложено кальция } \\
\hline & & & & & 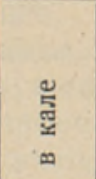 & $\begin{array}{l}\frac{0}{0} \\
\frac{\pi}{2} \\
\infty\end{array}$ & 号 & & 홍 & 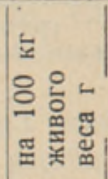 & 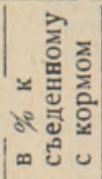 & 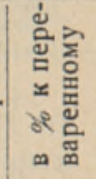 \\
\hline p & I & $\begin{array}{r}1 \\
1,2\end{array}$ & $\begin{array}{l}52,2 \\
64,5\end{array}$ & $\begin{array}{l}12,05 \\
15,42\end{array}$ & $\begin{array}{l}2.99 \\
2,21\end{array}$ & $\overline{-}$ & $\begin{array}{l}2,99 \\
2,21\end{array}$ & $\begin{array}{r}9,06 \\
13,21\end{array}$ & $\begin{array}{r}9,06 \\
13,21\end{array}$ & $\begin{array}{l}17,16 \\
20,48\end{array}$ & $\begin{array}{l}75,18 \\
85,67\end{array}$ & $\begin{array}{l}100 \\
100\end{array}$ \\
\hline Doph & $\begin{array}{l}1 \\
\text { II }\end{array}$ & $\begin{array}{l}3 \\
3\end{array}$ & $\begin{array}{r}98,8 \\
112,8\end{array}$ & $\begin{array}{l}24,40 \\
35,67\end{array}$ & & - & $\begin{array}{l}12,96 \\
20,21\end{array}$ & $\begin{array}{l}11,44 \\
16,46\end{array}$ & & $\begin{array}{l}11,58 \\
13,71\end{array}$ & $\begin{array}{l}46,89 \\
43,34\end{array}$ & $\begin{array}{l}100 \\
100\end{array}$ \\
\hline Третий & $\begin{array}{l}\text { I } \\
\text { II }\end{array}$ & $\begin{array}{l}6 \\
6\end{array}$ & $\begin{array}{l}184,8 \\
199,0\end{array}$ & $\begin{array}{l}57,65 \\
60,23\end{array}$ & $\begin{array}{l}35,77 \\
32,28\end{array}$ & $\overline{-}$ & $\begin{array}{l}35,77 \\
32,28\end{array}$ & $\begin{array}{l}21,88 \\
27,95\end{array}$ & & $\begin{array}{l}11,84 \\
14,05\end{array}$ & $\begin{array}{l}37,95 \\
46,41\end{array}$ & $\begin{array}{l}100 \\
100\end{array}$ \\
\hline Четвертый & I & $\begin{array}{l}9 \\
9\end{array}$ & $\begin{array}{l}249,0 \\
262,0\end{array}$ & $\begin{array}{l}56,58 \\
56,15\end{array}$ & & $\begin{array}{l}0,56 \\
0,60\end{array}$ & $\begin{array}{l}31,74 \\
26,70\end{array}$ & $\begin{array}{l}25,40 \\
30,05\end{array}$ & $\begin{array}{l}24,84 \\
29,45\end{array}$ & $\begin{array}{l}9,98 \\
9,42\end{array}$ & $\begin{array}{l}43,90 \\
52,45\end{array}$ & $\begin{array}{l}97,80 \\
98,00\end{array}$ \\
\hline Пятый & $\begin{array}{l}\text { I } \\
\text { II }\end{array}$ & $\begin{array}{l}12 \\
12\end{array}$ & $\begin{array}{l}312,5^{*} \\
335,3\end{array}$ & $\begin{array}{l}64,35^{*} \\
70,15\end{array}$ & $\begin{array}{l}26,31 \\
41,87\end{array}$ & $\begin{array}{l}0,85 \\
0,85\end{array}$ & $\begin{array}{l}27,16 \\
42,72\end{array}$ & $\begin{array}{l}38,04 \\
28,28\end{array}$ & $\begin{array}{l}37,19 \\
27,43\end{array}$ & $\begin{array}{r}11,90 \\
8,18\end{array}$ & $\begin{array}{l}57,79 \\
39,10\end{array}$ & $\begin{array}{l}97,77 \\
96,99\end{array}$ \\
\hline
\end{tabular}

Т а бли ц а 17

Обмен фосфора у телят

\begin{tabular}{|c|c|c|c|c|c|c|c|c|c|c|c|c|}
\hline \multirow[b]{2}{*}{$\begin{array}{c}\text { Периоды } \\
\text { опыта }\end{array}$} & \multirow[b]{2}{*}{ 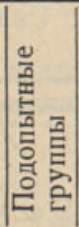 } & \multirow[b]{2}{*}{ 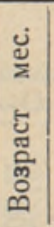 } & \multirow[b]{2}{*}{ 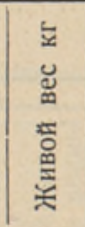 } & \multirow[b]{2}{*}{ 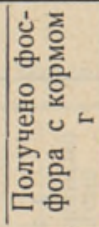 } & \multicolumn{3}{|c|}{ Выделено фосфора r } & \multirow[b]{2}{*}{ 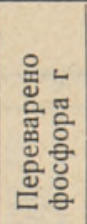 } & \multicolumn{4}{|c|}{ Отложено фосфора } \\
\hline & & & & & 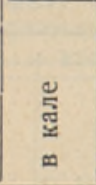 & $\begin{array}{l}\frac{0}{2} \\
\frac{0}{2} \\
\infty\end{array}$ & 芯 & & 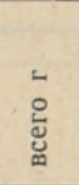 & 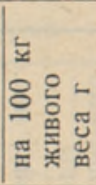 & 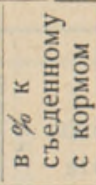 & 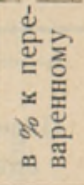 \\
\hline & $\begin{array}{l}\text { I } \\
\text { II }\end{array}$ & $\begin{array}{c}1 \\
1,2\end{array}$ & $\begin{array}{l}52,2 \\
64,5\end{array}$ & $\begin{array}{r}8,98 \\
13,30\end{array}$ & & & & $\begin{array}{r}8,49 \\
12,60\end{array}$ & & $\begin{array}{l}11,80 \\
14,42\end{array}$ & $\begin{array}{l}68,50 \\
69,92\end{array}$ & $\begin{array}{l}72,85 \\
73,33\end{array}$ \\
\hline Tonot & $\stackrel{\text { I }}{\text { II }}$ & $\begin{array}{l}3 \\
3\end{array}$ & $\begin{array}{r}98,8 \\
112,8\end{array}$ & $\begin{array}{l}18,84 \\
24,07\end{array}$ & $\begin{array}{l}4,46 \\
9,55\end{array}$ & & $\begin{array}{l}11,12 \\
14,80\end{array}$ & $\begin{array}{l}14,38 \\
14,52\end{array}$ & & $\begin{array}{l}7,81 \\
8,23\end{array}$ & $\begin{array}{l}40,98 \\
38,51\end{array}$ & $\begin{array}{l}53,67 \\
63,84\end{array}$ \\
\hline गетіп & $\begin{array}{l}\text { I } \\
\text { II }\end{array}$ & $\begin{array}{l}6 \\
6\end{array}$ & $\begin{array}{l}184,8 \\
199,0\end{array}$ & $\begin{array}{l}28,52 \\
30,51\end{array}$ & & & $\begin{array}{l}14,61 \\
15,28\end{array}$ & $\begin{array}{l}15,28 \\
16,52\end{array}$ & & $\begin{array}{l}7,53 \\
7,69\end{array}$ & $\begin{array}{l}48,77 \\
49,92\end{array}$ & $\begin{array}{l}91,03 \\
92,19\end{array}$ \\
\hline Четвертый & $\begin{array}{c}\text { I } \\
\text { II }\end{array}$ & $\begin{array}{l}9 \\
9\end{array}$ & $\begin{array}{l}249,0 \\
262,0\end{array}$ & $\begin{array}{l}36,42 \\
45,33\end{array}$ & & $\begin{array}{l}1,57 \\
1,26\end{array}$ & $\begin{array}{l}16,53 \\
24,69\end{array}$ & $\begin{array}{l}21,46 \\
21,90\end{array}$ & & $\begin{array}{l}7,99 \\
7,89\end{array}$ & $\begin{array}{l}54,61 \\
45,53\end{array}$ & $\begin{array}{l}92,68 \\
94,25\end{array}$ \\
\hline A 1 Hiton & I & $\begin{array}{l}12 \\
12\end{array}$ & $\begin{array}{l}306,5 \\
335,3\end{array}$ & $\begin{array}{l}35,60 \\
47,80\end{array}$ & $\begin{array}{l}15,03 \\
33,51\end{array}$ & $\begin{array}{l}2,15 \\
0,73\end{array}$ & $\begin{array}{l}17,18 \\
34,24\end{array}$ & $\begin{array}{l}20,57 \\
14,29\end{array}$ & & $\begin{array}{l}6,01 \\
4,04\end{array}$ & $\begin{array}{l}51,74 \\
28,37\end{array}$ & $\begin{array}{l}89,55 \\
94,89\end{array}$ \\
\hline
\end{tabular}

Все эти данные вместе с приведенными выше анализами по использованию кормов дают некоторые теоретические основы для составления кормовых норм и рационов для молодняка эстонской красной породы.

\section{Мясная продуктивность подопытного молодняка}

Поскольку мясная продуктивность эстонской красной породы еще недостаточно изучена, вопрос о мясных качествах этой породы представляет определенный хозяйственный и научный интерес.

\footnotetext{
* Средние данные по двум животным.
} 


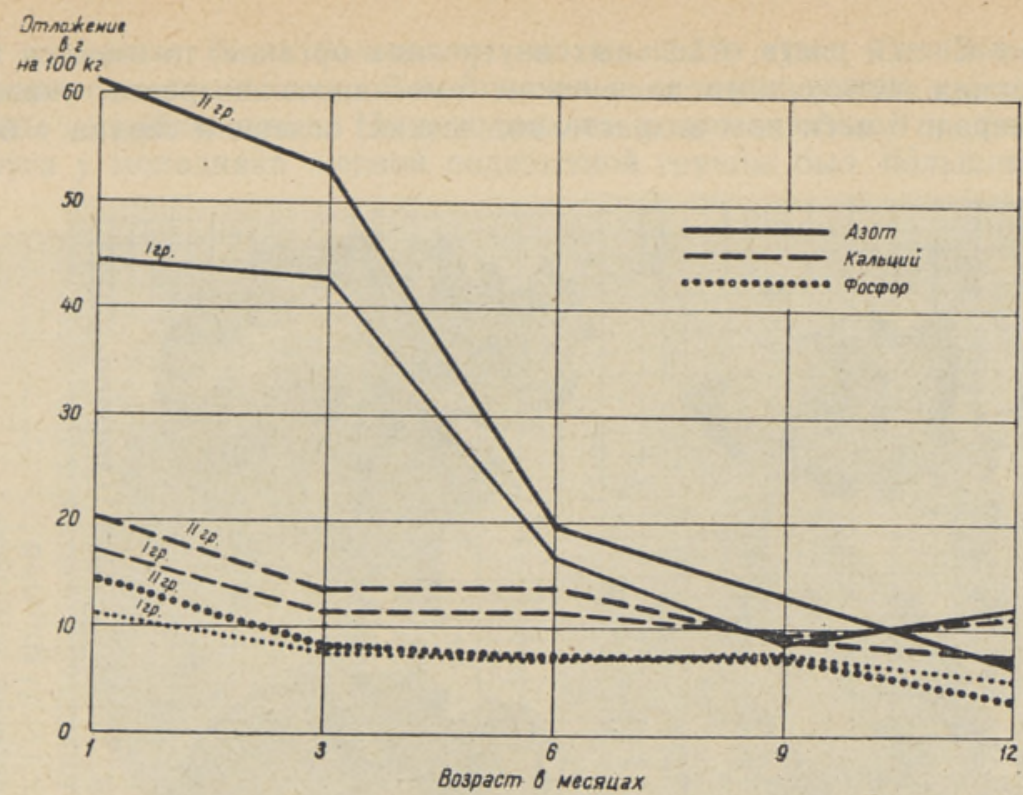

Рис. 6. Среднесуточное отложение азота, кальция и фосфора в теле подопытного молодняка в $\mathrm{r}$ (в среднем по двум группам)

Как видно из данных табл. 18, убойный выход бычков в возрасте 6 месяцев - 52,5-57,7\%, а бычков-кастратов в годовалом возрасте $56,5-57 \%$. Интересно отметить, что в опыте К. А. Акопяна (') бычкикастраты симментальской, шортгорнской и герефордской пород в возpacte 1,5 года после нагула на естественных выпасах давали убойный выход от 46,8 до $48,5 \%$. Результат забоя показывает, что у эстонской красной породы, разводимой до сих пор главным образом в качестве молочной породы, при обильном кормлении значительно повышается мясная продуктивность.

Т а бл и ца 18

Данные контрольного забоя бычков (по 4 головы в 6-месячном возрасте и по 6 голов в 12-месячном возрасте)

\begin{tabular}{|c|c|c|c|c|c|c|c|c|}
\hline \multirow{3}{*}{ Показатели } & \multicolumn{4}{|c|}{ I группа } & \multicolumn{4}{|c|}{ II группа } \\
\hline & \multicolumn{2}{|c|}{$\begin{array}{c}\text { В 6-месячн. } \\
\text { возрасте }\end{array}$} & \multicolumn{2}{|c|}{$\begin{array}{c}\text { В 12-месячн. } \\
\text { возрасте }\end{array}$} & \multicolumn{2}{|c|}{$\begin{array}{c}\text { В 6-месячн. } \\
\text { возрасте }\end{array}$} & \multicolumn{2}{|c|}{$\begin{array}{l}\text { В 12-месячн. } \\
\text { возрасте }\end{array}$} \\
\hline & $\mid \begin{array}{c}\text { Сред- } \\
\text { нее кг }\end{array}$ & $\%$ & $\begin{array}{l}\text { Сред- } \\
\text { нее кг }\end{array}$ & $\%$ & $\begin{array}{c}\text { Сред- } \\
\text { нее кг }\end{array}$ & $\%$ & $\begin{array}{l}\text { Сред- } \\
\text { нее кт }\end{array}$ & $\%$ \\
\hline $\begin{array}{l}\text { Живой вес перед отправление } \\
\text { на мясокомбинат }\end{array}$ & 203,5 & - & 336,0 & & 200,0 & - & 345,0 & - \\
\hline Живой вес перед забоем & 200,6 & 100 & 330,7 & 100 & 183,0 & 100 & 341,0 & 100 \\
\hline Туша & 105,5 & 52,62 & 190,1 & 57,18 & 105,5 & 57,65 & 192,7 & 56,51 \\
\hline Внугреннее сало & 5,11 & 2,55 & 21,30 & 6,44 & 5,89 & 3,22 & 24,34 & 7,14 \\
\hline Кровь & 9,67 & 4,82 & 13,85 & 4,19 & 9,05 & 4,95 & 14,23 & 4.17 \\
\hline Сердие & 1,18 & 0,59 & 1,65 & 0,50 & 1,03 & 0,53 & 1,87 & 0,55 \\
\hline Легкие & 2,02 & 1,01 & 2,57 & 0,78 & 1,82 & 0,99 & 2,65 & 0,78 \\
\hline Печень & 3,45 & 1,72 & 4,32 & 1,31 & 3,16 & 1,73 & 5,16 & 1,51 \\
\hline Почки & 0,67 & 0,33 & 0,88 & 0,27 & 0,75 & 0,41 & 1,08 & 0,32 \\
\hline Селезенка & 0,33 & 0,16 & 0,61 & 0,18 & 0,42 & 0,23 & 0,62 & 0,1 \\
\hline Рубец и сетка & 3,15 & 1,57 & 6,20 & 1,87 & 3,05 & 1,67 & 7,41 & 2,17 \\
\hline Книжка & 0,80 & 0,40 & 2,67 & 0,81 & 0,87 & 0,48 & 2,08 & 0,61 \\
\hline Сычуг & 0,67 & 0,33 & 1,21 & 0,37 & 0,65 & 0,36 & 1,31 & 0,38 \\
\hline Тонкие кишки & 3,68 & 1,84 & 4,33 & 1,31 & 3,59 & 1,96 & 4,79 & 1,40 \\
\hline Толстые кишки & 1,33 & 0,66 & 1,88 & 0,57 & 1,36 & 0,74 & 2,06 & 0,60 \\
\hline Кожа & 12,50 & 6,23 & 18,77 & 5,68 & 12,40 & 6,78 & 21,70 & 6,36 \\
\hline
\end{tabular}


Что касается роста отдельных внутренних органов, то имеется заметная разница между ними до и после 6-месячного возраста животных. Например, в 6-месячном возрасте вес легких, печени и сердца у бычков

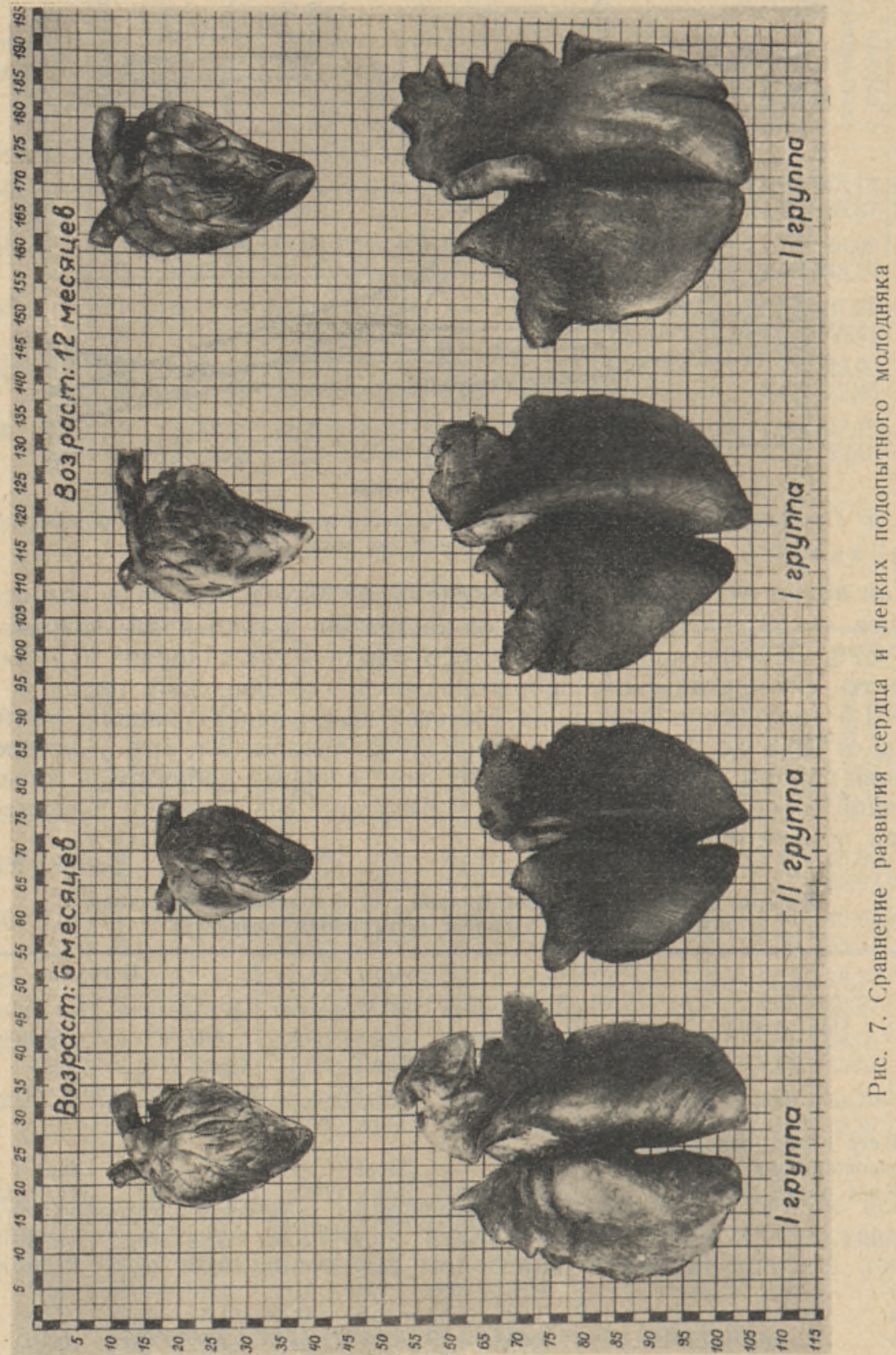

первой группы превышал соответствуюшие показатели второй группы на 11,12 и $15 \%$, но крови у животных первой группы было болыше на $7 \%$. В 12-месячном возрасте различия были обратными: вес легких, печени и сердца у животных второй группы превышал вес этих же органов у животных первой группы, соответственно, на 3, 19 !! 13\%, причем 
крови у первых было больше только на 2,7\% (рис. 7). В развитии пищеварительного канала в 6-месячном возрасте у животных значительной разницы не наблюдалось. Но в годовалом возрасте объем преджелудков и сычуга у молодняка первой подопытной группы был бо́льшим, чем у

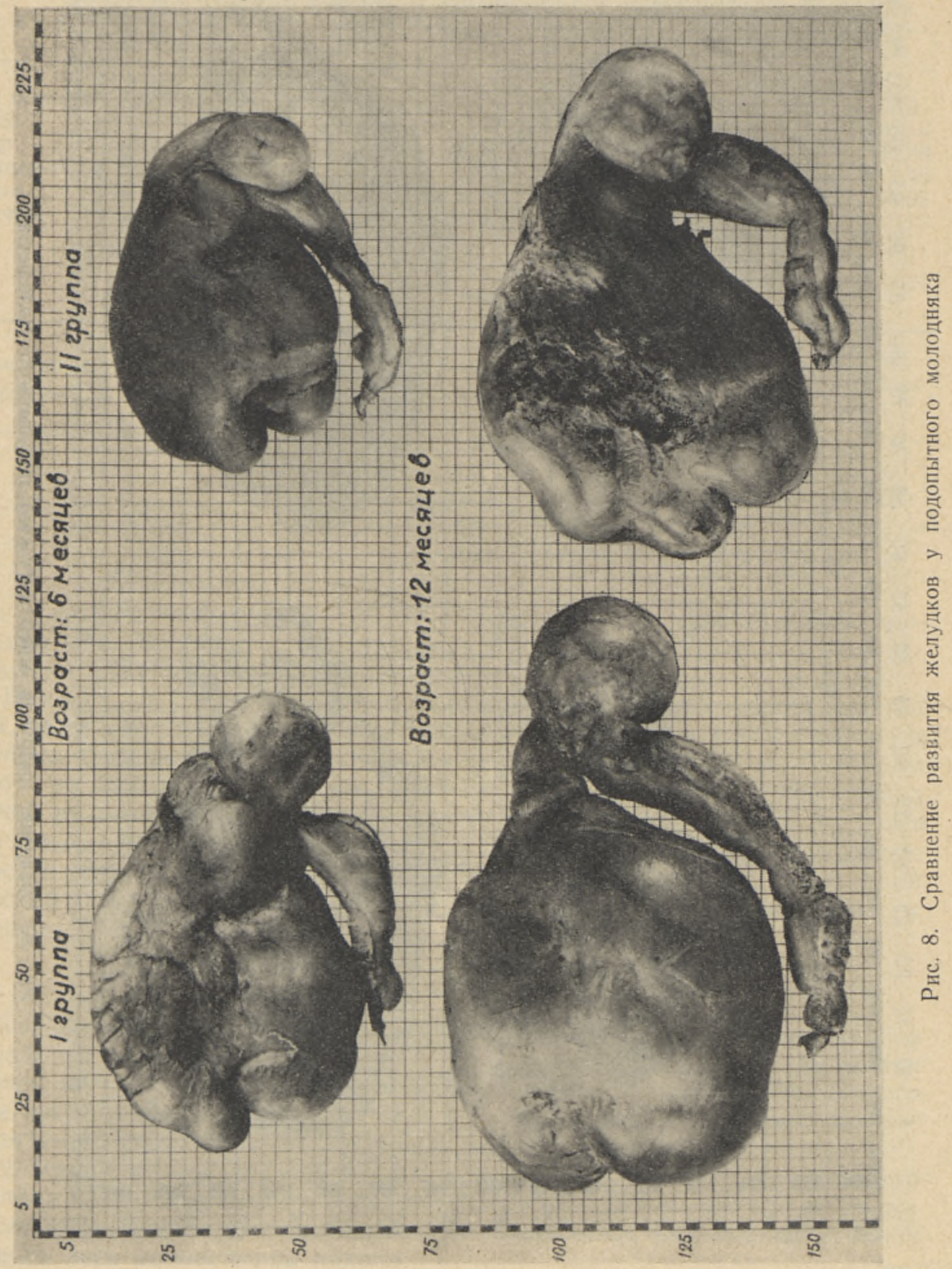

второй группы. Так, например, объем рубца и сетки у животных первой группы был в среднем 82 л, а у второй группы 64 л, длина кишечника, соответственно, 49 и 45 м (рис. 8).

Из табл. 19 видно, что с возрастом процент содержания в туше мяса (чистого) и костей падает, а содержание жира возрастает. Процент съе- 
добной части туши бычков-кастратов в возрасте от 6 до 12 месяцев заметно повышается, в то же время значительно возрастает и ее питательная ценность (табл, 20).

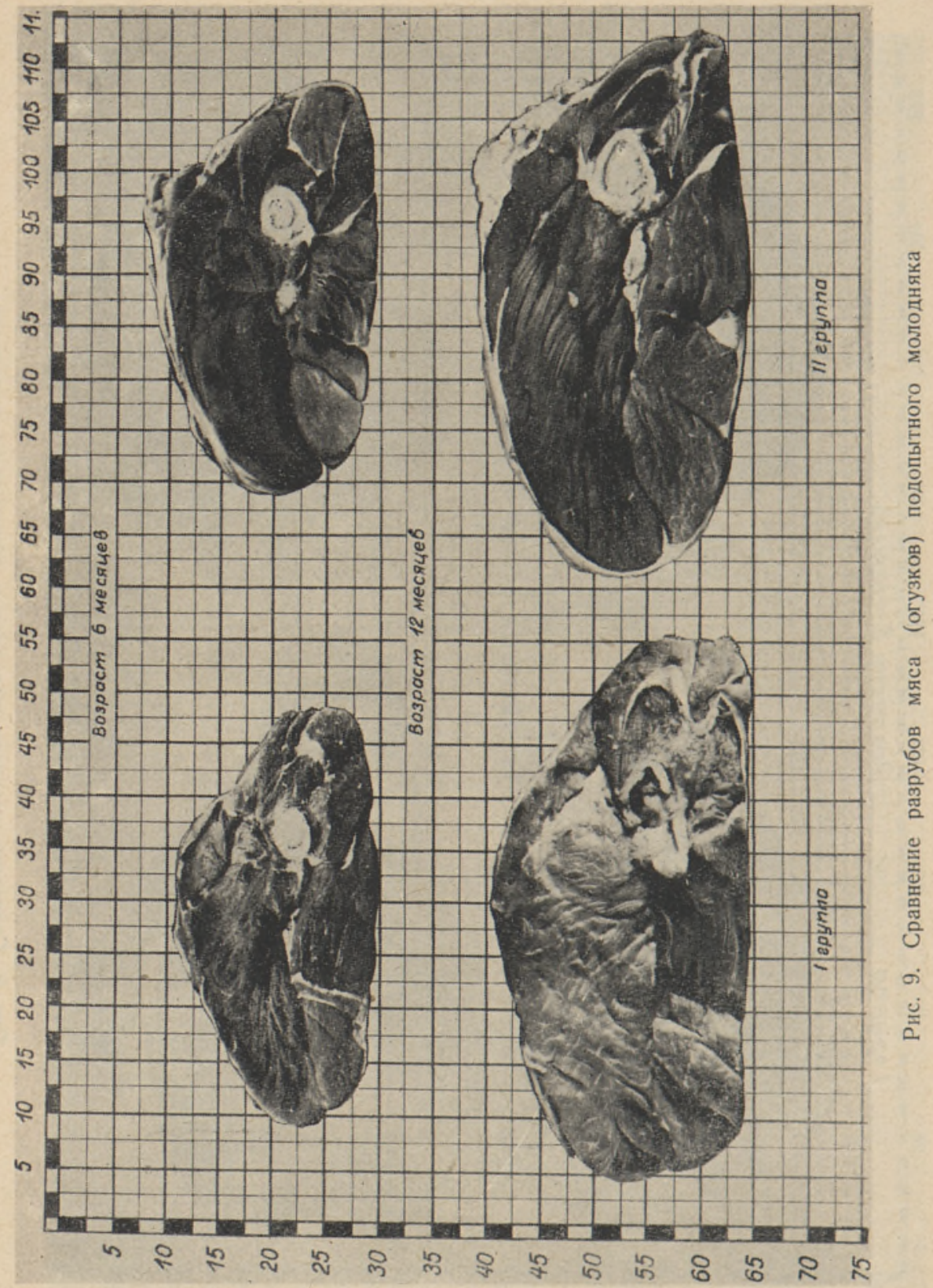

Кроме высокой калорийности, мясо подопытных животных отличалось прекрасными вкусовыми качествами, как его оценили по дегустации потребители, а также высокой сортностью.

Следует отметить то обстоятельство, что вторая группа кастратов в 12-месячном возрасте, несмотря на более обильное кормление молоком и концентратами, уступает первой группе как по выходу мясной продукции, 
Результаты обвалки туш подопытных животных

\begin{tabular}{|c|c|c|c|c|c|c|c|c|}
\hline \multirow{3}{*}{ Показатели } & \multicolumn{4}{|c|}{ I rpynna } & \multicolumn{4}{|c|}{ II группа } \\
\hline & \multicolumn{2}{|c|}{$\begin{array}{l}\text { В возрасте } \\
6 \text { месяцев }\end{array}$} & \multicolumn{2}{|c|}{$\begin{array}{l}\text { В возрасте } \\
12 \text { месяцев }\end{array}$} & \multicolumn{2}{|c|}{$\begin{array}{l}\text { В возрасте } \\
6 \text { месяцев }\end{array}$} & \multicolumn{2}{|c|}{$\begin{array}{l}\text { В возрасте } \\
12 \text { месяцев }\end{array}$} \\
\hline & кГ & $\%$ & кГ & $\%$ & KГ & $\%$ & кГ & $\%$ \\
\hline $\begin{array}{l}\text { Вес остывшей туши } \\
\text { Мясо } \\
\text { Жир } \\
\text { Сухожилия и связки } \\
\text { Кости } \\
\text { Потери }\end{array}$ & $\begin{array}{r}105,5 \\
73,74 \\
2,37 \\
6,57 \\
21,84 \\
1,00\end{array}$ & $\begin{array}{r}100,0 \\
69,89 \\
2,24 \\
6,23 \\
20,70 \\
0,94\end{array}$ & $\begin{array}{r}190,1 \\
117,84 \\
24,19 \\
12,19 \\
35,00 \\
0,88\end{array}$ & $\begin{array}{r}100,0 \\
61,99 \\
12,72 \\
6,41 \\
18,41 \\
0,47\end{array}$ & \begin{tabular}{r|r}
105,5 \\
72,26 \\
3,70 \\
5,78 \\
23,46 \\
0,30
\end{tabular} & $\begin{array}{r}100,0 \\
68,49 \\
3,51 \\
5,48 \\
22,24 \\
0,28\end{array}$ & $\begin{array}{r}192,7 \\
117,80 \\
22,92 \\
14,37 \\
37,29 \\
0,32\end{array}$ & $\begin{array}{r}100,0 \\
61,13 \\
11,89 \\
7,46 \\
19,35 \\
0,17\end{array}$ \\
\hline
\end{tabular}

Химический состав мяса подопытных животных

\begin{tabular}{c|c|c|c|c|c|c}
\hline $\begin{array}{c}\text { Подопытные } \\
\text { группы }\end{array}$ & $\begin{array}{c}\text { Возраст } \\
\text { мес. }\end{array}$ & $\begin{array}{c}\text { Вода } \\
\%\end{array}$ & $\begin{array}{c}\text { Белок } \\
\%\end{array}$ & $\begin{array}{c}\text { Жир } \\
\%\end{array}$ & $\begin{array}{c}\text { Зола } \\
\%\end{array}$ & $\begin{array}{c}\text { Калорий- } \\
\text { ность 1 кг } \\
\text { мяса }\end{array}$ \\
\hline I & 6 & 72,14 & 22,29 & 4,45 & 1,12 & 1712,3 \\
II & 6 & 71,72 & 20,52 & 5,74 & 1,07 & 1746,9 \\
I & 12 & 62,96 & 18,60 & 17,58 & 0,86 & 2725,6 \\
II & 12 & 63,61 & 18,50 & 16,77 & 0,91 & 2647,7 \\
\end{tabular}

так и по питательной ценности ее. Вследствие этого себестоимость продукции мяса при типе кормления первой подопытной группы будет значительно ниже по сравнению со второй группой.

Наконец, необходимо отметить еще одну особенность мясной продукции скота эстонской красной породы. Хотя выход съедобной части туш забитых бычков-кастратов не уступает по количеству мясным породам скота, но жир у животных эстонской красной породы откладывается под кожей на поверхности туши и между отдельными группами мышц более или менее массивными прослойками, а не равномерно в мускулатуре (рис. 9). Это явление и служит причиной того, что мясо скота эстонской красной породы не имеет «мраморной» структуры, как это бывает у типично мясных пород скота.

\section{Выводы}

1. Расходование питательных веществ на каждые 100 кг живого веса молодняка закономерно падает с 1-до 12-месячного возраста. Если при данной интенсивности роста и развития в первом месяце на 100 кг живого веса потребовалось 4,37 кг кормовых единиц в сутки, то в годовалом возрасте количество потребных кормовых единиц снизилось до 1,87 кг.

2. Закономерное повышение потребления сухого вещества кормового рациона на единицу живого веса замечалось с 4- до 9-месячного возраста. После этого возраста потребление сухого вещества рациона на единицу живого веса закономерно падало.

Эти данные вместе с показателями по усвояемости питательных веществ могут служить основой для составления норм кормления и оценки питательной ценности кормов для растущего молодняка крупного рогатого скота эстонской красной породы.

3. Опыты показывают, что интенсивное кормление улучшает выход мяса и жира у бычков-кастратов и повышает питательную ценность до 
степени, характерной для специально мясных пород скота. Но мясо животных эстонского красного скота, как молочной породы, не имеет «мраморной» структуры даже при обильном кормлении.

4. Результаты опытов показывают, что тип кормления второй подопытной группы («обильно молочный») не оправдывает себя в отношении роста и развития телосложения молодняка, а также по мясной продукции и является экономически невыгодным. Этот вывод особенно важен и поучителен для некоторых племенных совхозов Әстонской ССР, в которых практикуется обильное кормление растущего молодняка молоком и концентратами.

Ннститут животноводства и ветеринарии Академии Наук Эстонской ССР

\section{ЛИТЕРАТУРА}

1. К. А. А ко пя н, Сравнение мясных качеств бычков-кастратов разных пород при нагуле их на естественных выпасах юго-востока СССР, «Вестник животноводства», вып. 3, 1947, стр. $21-34$.

2. Л. И. Д р а к и, Обмен веществ и энергии у телят. Труды Всесоюзного научноисследовательского института животноводства, т. 8, Сельхозгиз, Москва, 1950.

3. И. А. Л ебеде в и А. П. С ем н нв, Опыт выращивания телок в колхозе имени Тельмана, «Советская зоотехника», № 3, 1951, стр. 38-52.

4. С. И. Ш т й м а н, Совершенствование молочного стада, Сельхозгиз, 1950.

5. В. И. Фе д оров, Ритмичность роста животных. Дисс. на соиск. уч. ст. д-ра биол: наук. Чкалов, 1946. 